Nat. Hazards Earth Syst. Sci., 22, 323-344, 2022

https://doi.org/10.5194/nhess-22-323-2022

(C) Author(s) 2022. This work is distributed under the Creative Commons Attribution 4.0 License.

\title{
A geography of drought indices: mismatch between indicators of drought and its impacts on water and food securities
}

\author{
Sarra Kchouk ${ }^{1}$, Lieke A. Melsen ${ }^{2}$, David W. Walker ${ }^{1}$, and Pieter R. van Oel ${ }^{1}$ \\ ${ }^{1}$ Water Resources Management Group, Wageningen University, Wageningen, 6708PB, The Netherlands \\ ${ }^{2}$ Hydrology and Quantitative Water Management Group, Wageningen University, Wageningen, 6708PB, The Netherlands
}

Correspondence: Sarra Kchouk (sarra.kchouk@wur.nl)

Received: 21 May 2021 - Discussion started: 17 June 2021

Revised: 22 December 2021 - Accepted: 23 December 2021 - Published: 7 February 2022

\begin{abstract}
Drought monitoring and early warning systems (DEWSs) are seen as helpful tools to tackle drought at an early stage and reduce the possibility of harm or loss. They usually include indices attributed to meteorological, agricultural and/or hydrological drought: physically based drought drivers. These indices are used to determine the onset, end and severity of a drought event. Drought impacts, like water and food securities, are less monitored or even not included in DEWSs. Therefore, the likelihood of experiencing these impacts is often simply linearly linked to drivers of drought. The aim of this study is to evaluate the validity of the assumed direct linkage between drivers of drought and water and food insecurity impacts of drought. We reviewed scientific literature on both drivers and impacts of drought. We conducted a bibliometric analysis based on 5000+ scientific studies in which selected drought indices (drivers) and drought-related water and food insecurities (impacts) were mentioned in relation to a geographic area. Our review shows that there is a tendency in scientific literature to focus on drivers of drought, with the preferred use of meteorological and remotely sensed drought indices. Studies reporting drought impacts are more localised, with relatively many studies focusing on sub-Saharan Africa and Australasia for impacts with regard to food security and water security, respectively. Our review further suggests that studies of food and water insecurity impacts related to drought are dependent on both the physical and human processes occurring in the geographic area, i.e. the local context. With the aim of increasing the relevance and utility of the information provided by DEWSs, we argue in favour of additional consideration of drought impact indices oriented towards sustainable development and human welfare.
\end{abstract}

\section{Introduction}

Drought is a threat to a wide range of human activities in virtually all climate zones and countries (Van Loon et al., 2016a; Bachmair et al., 2016; Van Lanen et al., 2017). It is an elusive phenomenon without a clear onset and demise. In contrast to other hazards such as floods, landslides or earthquakes, drought has a creeping nature causing impacts to persist for many years (Kim et al., 2019). Consequently, impacts can be cumulative for consecutive periods of droughts, devastating both ecosystems and societies (Bachmair et al., 2016; Van Lanen et al., 2017).

Many concepts exist for defining a drought (Santos Pereira et al., 2009; Lloyd-Hughes, 2014). Definitions of drought are either conceptual or operational. Conceptual definitions of drought are descriptive and highlight the natural hazard element: for example, precipitation below what is expected or normal (Knutson et al., 1998). Operational definitions of drought highlight practical implications in an attempt to identify the onset, severity and cessation of drought periods (Mishra and Singh, 2010). For example, the UN Convention to Combat Drought and Desertification (UN Secretariat General, 1994) defines drought as "when precipitation has been significantly below normal recorded levels, causing serious hydrological imbalances that adversely affect land resource production systems".

The numerical value of hydro-climatic variables is associated with three main types of drought: meteorological, agricultural (or soil moisture) and hydrological droughts. These variables are in fact drivers, which refer to the contributing or counteracting factors that affect the development of droughts (Seneviratne, 2012). Those drivers are used by many drought 
studies as the framework to represent drought propagation. In the literature, the temporal propagation of drought is often considered to be a sequence occurring in an almost linear order (Wilhite and Glantz, 1985; Zargar et al., 2011; Bachmair et al., 2016) and in which humans have no direct influence. This is a simplification of a complex process, in which it is considered that an anomaly (e.g. lower precipitation, higher temperature than average) of the values of those drivers will lead to a cascade reaction influencing the magnitude of other physical variables and leading in turn to the subsequent type of drought. As such, hydrological drought is inaccurately simplified as a result of the persistence in duration of agricultural (soil moisture) drought, which itself is simplistically attributed to the persistence of meteorological drought.

Drought monitoring and early warning systems (DEWSs) aim to monitor the drivers of drought to predict drought. They aim to tackle drought at an early stage to reduce the possibility of harm or loss. For assessing the severity of a drought, physical variables are usually translated into indices of drought. The difference between their values and the threshold used to define the level of dryness is considered to depict the severity of a drought (Vogt et al., 2018). Drought impacts, such as water and food security, are rarely continuously monitored or even included in DEWSs. This is understandable as there is already a plethora of definitions for drought and drought types, and there are at least as many possibilities for defining impacts (Mishra and Singh, 2010; Wilhite, 2000; Santos Pereira et al., 2009). Drought impacts are non-structural, difficult to quantify or monetise, and can be direct or indirect due to the extended nature, in time and area, of drought (Wilhite et al., 2007; Logar and Van den Bergh, 2011; Bachmair et al., 2016). In addition, most of the DEWSs do not take the underlying vulnerabilities of the drought-affected or drought-monitored areas into account. Thus, in the current configuration of most DEWSs, the presumed likelihood of experiencing impacts is mainly linked to the severity of climatic features only (e.g. Princeton Flood and Drought Monitors, 2021; U.S. Drought Monitor, 2021; Brazilian Drought Monitor, 2021).

This study aims to review scientific reporting on drought drivers and drought impacts for affected countries and analyse how these two compare. Improving our understanding of the linkage and separation between drought drivers and drought impacts enables us to provide directions to further improve the accuracy of the information provided by DEWSs. We retrieved scientific studies from countries in which selected drivers of drought and food and water security impacts of drought are mentioned. The components of drought drivers and impacts on which the literature focused were explored and compared for different areas of the world.

\section{Data and methods}

\subsection{Methodological approach}

The methodological approach comprises three steps:

- Step 1. Exploring which drought drivers are the most recurrent in the scientific literature. We investigated which indices of drought drivers are most frequently used in scientific drought-related studies and to what drought type they were linked. For each of these scientific studies we also retrieved the country of focus. This allowed us to identify the most frequently mentioned type of drought for different geographic regions and the prevalent drought indices used in scientific studies.

- Step 2. Exploring which drought impacts are the most recurrent in the scientific literature. In contrast with drought drivers, for drought impacts there are no established indices commonly used in DEWSs and in scientific studies. We thus retrieved from scientific articles keywords associated with drought impacts related to water security and food security. This allowed the identification of the most frequently mentioned waterand food-related drought impacts.

- Step 3. Comparing the findings of Steps 1 and 2. This enabled the evaluation of the alignment between reported drought types and impacts, with regard to the number of publications and differences in geographic focus.

\subsection{Data}

We considered the number of studies about drought indices and drought impacts and their geographical distribution as our units. Our list of drought indices is based on two prominent studies in the field of drought indices: indices commonly used operationally to depict different types of drought (Svoboda and Fuchs, 2016) and the indices commonly used by water managers (Bachmair et al., 2016). Our list will, however, inherently be incomplete because many other indices exist beyond the ones mentioned in these two studies. This resulted in 32 indices that we linked to three main drought types (Table 1): meteorological (9 indices), soil moisture/agricultural (15) and hydrological (8) drought.

We opted for Scopus to retrieve the scientific publications of interest as it is the database covering the largest range of both peer-reviewed literature type (scientific journals, books and conference proceedings) and disciplinary fields (science, technology, medicine, social sciences, and arts and humanities) (Scopus, 2021). We then searched in the Scopus database for queries strictly including "drought" AND "[the index]" in the title, abstract and authors' keywords of the studies. We repeated the queries for each index individually as we were interested in knowing country-based preferences. The sum of the individual indices linked to drought queries 
Table 1. Table of the drought indices and impacts sought in studies retrieved from Scopus. Their acronym, input data when applicable, total number of studies and number of studies mentioning a country are detailed.

\begin{tabular}{|c|c|c|c|c|c|c|}
\hline $\begin{array}{l}\text { Meteorological } \\
\text { drought } \\
\text { index studies }\end{array}$ & \multicolumn{2}{|c|}{$\begin{array}{l}\text { Total number of studies of } \\
\text { drought indices: } 5567\end{array}$} & \multicolumn{2}{|c|}{$\begin{array}{l}\text { Total number of studies } \\
\text { mentioning a country: } \\
\qquad 4023\end{array}$} & $\begin{array}{r}\text { Studies not } \\
\text { mentioning } \\
\text { a country: } \\
27.7 \%\end{array}$ & $\begin{array}{l}\text { Top three subject areas retrieved } \\
\text { from Scopus }\end{array}$ \\
\hline $\begin{array}{l}\text { "Meteorological } \\
\text { drought" indices } \\
\text { mentioned in the } \\
\text { study }\end{array}$ & Acronym & Input data & $\begin{array}{r}\text { Number } \\
\text { of } \\
\text { studies }\end{array}$ & $\begin{array}{r}\text { Studies } \\
\text { mentioning } \\
\text { a country }\end{array}$ & $\begin{array}{r}\text { Portion of } \\
\text { studies not } \\
\text { mentioning a } \\
\text { country }(\%)\end{array}$ & \\
\hline $\begin{array}{l}\text { Standardised } \\
\text { precipitation } \\
\text { index }\end{array}$ & SPI & Precipitation & 2451 & 1812 & 26.1 & $\begin{array}{l}\text { (1) Environmental science } \\
\text { (2) Earth and planetary sciences } \\
\text { (3) Agricultural and biological sciences }\end{array}$ \\
\hline $\begin{array}{l}\text { Standardised } \\
\text { precipitation } \\
\text { evapotranspira- } \\
\text { tion index }\end{array}$ & SPEI & $\begin{array}{l}\text { Precipitation, } \\
\text { temperature }\end{array}$ & 1059 & 751 & 29 & $\begin{array}{l}\text { (1) Environmental science } \\
\text { (2) Earth and planetary sciences } \\
\text { (3) Agricultural and biological sciences }\end{array}$ \\
\hline Aridity index & AI & $\begin{array}{l}\text { Precipitation, } \\
\text { temperature }\end{array}$ & 247 & 182 & 26.3 & $\begin{array}{l}\text { (1) Environmental science } \\
\text { (2) Earth and planetary sciences } \\
\text { (3) Agricultural and biological sciences }\end{array}$ \\
\hline $\begin{array}{l}\text { Precipitation } \\
\text { deciles }\end{array}$ & Deciles & Precipitation & 12 & 9 & 25 & $\begin{array}{l}\text { (1) Earth and planetary sciences } \\
\text { (2) Environmental science } \\
\text { (3) Engineering }\end{array}$ \\
\hline $\begin{array}{l}\text { Keetch-Byram } \\
\text { drought index }\end{array}$ & KBDI & $\begin{array}{l}\text { Precipitation, } \\
\text { temperature }\end{array}$ & 84 & 66 & 21.4 & $\begin{array}{l}\text { (1) Environmental science } \\
\text { (2) Agricultural and biological sciences } \\
\text { (3) Earth and planetary sciences }\end{array}$ \\
\hline $\begin{array}{l}\text { Palmer drought } \\
\text { severity index }\end{array}$ & PDSI & $\begin{array}{l}\text { Precipitation, } \\
\text { temperature, } \\
\text { available } \\
\text { water } \\
\text { content }\end{array}$ & 1279 & 867 & 32.2 & $\begin{array}{l}\text { (1) Environmental science } \\
\text { (2) Earth and planetary sciences } \\
\text { (3) Agricultural and biological sciences }\end{array}$ \\
\hline $\begin{array}{l}\text { Percent of nor- } \\
\text { mal precipitation } \\
\text { (index) }\end{array}$ & PNPI & Precipitation & 23 & 18 & 21.7 & $\begin{array}{l}\text { (1) Environmental science } \\
\text { (2) Earth and planetary sciences } \\
\text { (3) Agricultural and biological sciences }\end{array}$ \\
\hline $\begin{array}{l}\text { Rainfall } \\
\text { anomaly } \\
\text { index }\end{array}$ & RAI & Precipitation & 304 & 244 & 19.7 & $\begin{array}{l}\text { (1) Earth and planetary sciences } \\
\text { (2) Environmental science } \\
\text { (3) Agricultural and biological sciences }\end{array}$ \\
\hline $\begin{array}{l}\text { Self-calibrated } \\
\text { Palmer drought } \\
\text { severity index }\end{array}$ & scPDSI & $\begin{array}{l}\text { Precipitation, } \\
\text { temperature, } \\
\text { available } \\
\text { water } \\
\text { content }\end{array}$ & 108 & 74 & 31.5 & $\begin{array}{l}\text { (1) Earth and planetary sciences } \\
\text { (2) Environmental science } \\
\text { (3) Agricultural and biological sciences }\end{array}$ \\
\hline
\end{tabular}


Table 1. Continued.

\begin{tabular}{|c|c|c|c|c|c|c|}
\hline $\begin{array}{l}\text { Agricultural and } \\
\text { soil moisture } \\
\text { drought index } \\
\text { studies }\end{array}$ & \multicolumn{2}{|c|}{$\begin{array}{l}\text { Total number of studies of drought } \\
\text { indices: } 5085\end{array}$} & \multicolumn{2}{|c|}{$\begin{array}{l}\text { Total number of studies } \\
\text { mentioning a country: } \\
\qquad 3137\end{array}$} & $\begin{array}{r}\text { Studies not } \\
\text { mentioning } \\
\text { a country: } \\
38.3 \%\end{array}$ & Top three subject areas \\
\hline $\begin{array}{l}\text { "Agricultural } \\
\text { drought" indices } \\
\text { mentioned in } \\
\text { the study }\end{array}$ & Acronym & Input data & $\begin{array}{r}\text { Number } \\
\text { of } \\
\text { studies }\end{array}$ & $\begin{array}{r}\text { Studies } \\
\text { mentioning } \\
\text { a country }\end{array}$ & $\begin{array}{r}\text { Portion of } \\
\text { studies not } \\
\text { mentioning a } \\
\text { country (\%) }\end{array}$ & \\
\hline $\begin{array}{l}\text { Crop moisture } \\
\text { index }\end{array}$ & CMI & $\begin{array}{l}\text { Precipitation, tempera- } \\
\text { ture }\end{array}$ & 43 & 20 & 53.5 & $\begin{array}{l}\text { (1) Earth and planetary } \\
\text { sciences } \\
\text { (2) Agricultural and } \\
\text { biological sciences } \\
\text { (3) Environmental science }\end{array}$ \\
\hline $\begin{array}{l}\text { Evaporative stress } \\
\text { index }\end{array}$ & ESI & $\begin{array}{l}\text { Remotely sensed poten- } \\
\text { tial evapotranspiration }\end{array}$ & 88 & 42 & 53.3 & $\begin{array}{l}\text { (1) Agricultural and } \\
\text { biological sciences } \\
\text { (2) Earth and planetary } \\
\text { sciences } \\
\text { (3) Environmental science }\end{array}$ \\
\hline $\begin{array}{l}\text { Evapotranspiration } \\
\text { deficit index }\end{array}$ & ETDI & $\begin{array}{l}\text { Soil water in the root } \\
\text { zone on a weekly basis, } \\
\text { which is computed from } \\
\text { SWAT (Soil and Water } \\
\text { Assessment Tool) model }\end{array}$ & 17 & 13 & 23.5 & $\begin{array}{l}\text { (1) Environmental science } \\
\text { (2) Earth and planetary } \\
\text { sciences } \\
\text { (3) Agricultural and } \\
\text { biological sciences }\end{array}$ \\
\hline $\begin{array}{l}\text { Enhanced vegeta- } \\
\text { tion index }\end{array}$ & EVI & $\begin{array}{l}\text { NIR/red/blue surface re- } \\
\text { flectances, canopy back- } \\
\text { ground adjustment, co- } \\
\text { efficients of the aerosol } \\
\text { resistance for correction } \\
\text { for aerosol influences in } \\
\text { the red band. }\end{array}$ & 305 & 206 & 32.2 & $\begin{array}{l}\text { (1) Earth and planetary } \\
\text { sciences } \\
\text { (2) Environmental science } \\
\text { (3) Agricultural and } \\
\text { biological sciences }\end{array}$ \\
\hline $\begin{array}{l}\text { Normalised } \\
\text { difference } \\
\text { vegetation index }\end{array}$ & NDVI & $\begin{array}{l}\text { Spectral reflectance mea- } \\
\text { surements acquired in the } \\
\text { red and near-infrared re- } \\
\text { gions }\end{array}$ & 2041 & 1288 & 36.9 & $\begin{array}{l}\text { (1) Earth and planetary } \\
\text { sciences } \\
\text { (2) Environmental science } \\
\text { (3) Agricultural and } \\
\text { biological sciences }\end{array}$ \\
\hline Leaf area index & LAI & Leaf and ground area & 1152 & 583 & 49.4 & $\begin{array}{l}\text { (1) Agricultural and } \\
\text { biological sciences } \\
\text { (2) Environmental science } \\
\text { (3) Earth and planetary } \\
\text { sciences }\end{array}$ \\
\hline $\begin{array}{l}\text { Palmer moisture } \\
\text { anomaly index } \\
- \text { known as the } \\
\text { Palmer } \mathrm{Z} \text { index }\end{array}$ & PZI & $\begin{array}{l}\text { Derivative of the PDSI } \\
\text { calculation precipitation, } \\
\text { temperature, available } \\
\text { water content }\end{array}$ & 47 & 30 & 36.2 & $\begin{array}{l}\text { (1) Earth and planetary } \\
\text { sciences } \\
\text { (2) Environmental science } \\
\text { (3) Agricultural and } \\
\text { biological sciences }\end{array}$ \\
\hline
\end{tabular}


Table 1. Continued.

\begin{tabular}{|c|c|c|c|c|c|c|}
\hline $\begin{array}{l}\text { Agricultural and } \\
\text { soil moisture } \\
\text { drought index } \\
\text { studies }\end{array}$ & \multicolumn{2}{|c|}{$\begin{array}{l}\text { Total number of studies of drought } \\
\text { indices: } 5085\end{array}$} & \multicolumn{2}{|c|}{$\begin{array}{l}\text { Total number of studies } \\
\text { mentioning a country: } \\
3137\end{array}$} & $\begin{array}{r}\text { Studies not } \\
\text { mentioning } \\
\text { a country: } \\
38.3 \%\end{array}$ & Top three subject areas \\
\hline $\begin{array}{l}\text { "Agricultural } \\
\text { drought" indices } \\
\text { mentioned in } \\
\text { the study }\end{array}$ & Acronym & Input data & $\begin{array}{r}\text { Number } \\
\text { of } \\
\text { studies }\end{array}$ & $\begin{array}{r}\text { Studies } \\
\text { mentioning } \\
\text { a country }\end{array}$ & $\begin{array}{r}\text { Portion of } \\
\text { studies not } \\
\text { mentioning a } \\
\text { country (\%) }\end{array}$ & \\
\hline $\begin{array}{l}\text { Soil adjusted } \\
\text { vegetation index }\end{array}$ & SAVI & $\begin{array}{l}\text { Spectral reflectance } \\
\text { measurements acquired } \\
\text { in the red and near- } \\
\text { infrared regions, with } \\
\text { the addition of a soil } \\
\text { brightness correction } \\
\text { factor }\end{array}$ & 68 & 37 & 45.6 & $\begin{array}{l}\text { (1) Agricultural and biologi- } \\
\text { cal sciences } \\
\text { (2) Environmental science } \\
\text { (3) Earth and planetary } \\
\text { sciences }\end{array}$ \\
\hline $\begin{array}{l}\text { Soil moisture } \\
\text { anomaly }\end{array}$ & SMA & $\begin{array}{l}\text { Precipitation, temper- } \\
\text { ature, available water } \\
\text { content }\end{array}$ & 138 & 87 & 37.0 & $\begin{array}{l}\text { (1) Earth and planetary } \\
\text { sciences } \\
\text { (2) Environmental science } \\
\text { (3) Agricultural and biologi- } \\
\text { cal sciences }\end{array}$ \\
\hline $\begin{array}{l}\text { Soil moisture } \\
\text { deficit index }\end{array}$ & SMDI & $\begin{array}{l}\text { Soil water in the root } \\
\text { zone on a weekly ba- } \\
\text { sis, which is computed } \\
\text { from SWAT model }\end{array}$ & 13 & 10 & 23.1 & $\begin{array}{l}\text { (1) Environmental science } \\
\text { (2) Earth and planetary } \\
\text { sciences } \\
\text { (3) Agricultural and biologi- } \\
\text { cal sciences }\end{array}$ \\
\hline $\begin{array}{l}\text { Soil water } \\
\text { deficit index }\end{array}$ & SWDI & & 33 & 26 & 21.2 & $\begin{array}{l}\text { (1) Earth and planetary } \\
\text { sciences } \\
\text { (2) Environmental science } \\
\text { (3) Agricultural and biologi- } \\
\text { cal sciences }\end{array}$ \\
\hline $\begin{array}{l}\text { Soil water } \\
\text { storage }\end{array}$ & SWS & $\begin{array}{l}\text { Available water con- } \\
\text { tent, reservoir, soil type, } \\
\text { soil water deficit }\end{array}$ & 717 & 494 & 31.1 & $\begin{array}{l}\text { (1) Agricultural and biologi- } \\
\text { cal sciences } \\
\text { (2) Environmental science } \\
\text { (3) Earth and planetary } \\
\text { sciences }\end{array}$ \\
\hline $\begin{array}{l}\text { Vegetation con- } \\
\text { dition index }\end{array}$ & VCI & (Same as) NDVI & 271 & 187 & 30.1 & $\begin{array}{l}\text { (1) Earth and planetary } \\
\text { sciences } \\
\text { (2) Environmental science } \\
\text { (3) Computer science }\end{array}$ \\
\hline $\begin{array}{l}\text { Vegetation } \\
\text { drought } \\
\text { response index }\end{array}$ & VegDRI & $\begin{array}{l}\text { SPI, PDSI, percentage } \\
\text { annual seasonal green- } \\
\text { ness, start of season } \\
\text { anomaly, land cover, } \\
\text { soil available water ca- } \\
\text { pacity, irrigated agri- } \\
\text { culture and defined eco- } \\
\text { logical regions }\end{array}$ & 14 & 13 & 7.1 & $\begin{array}{l}\text { (1) Earth and planetary } \\
\text { sciences } \\
\text { (2) Environmental science } \\
\text { (3) Agricultural and biologi- } \\
\text { cal sciences }\end{array}$ \\
\hline $\begin{array}{l}\text { Vegetation health } \\
\text { index }\end{array}$ & VHI & $\begin{array}{l}\text { NDVI and brightness } \\
\text { temperature, both from } \\
\text { thermal bands }\end{array}$ & 138 & 101 & 26.8 & $\begin{array}{l}\text { (1) Earth and planetary } \\
\text { sciences } \\
\text { (2) Environmental science } \\
\text { (3) Computer science }\end{array}$ \\
\hline
\end{tabular}


Table 1. Continued.

\begin{tabular}{|c|c|c|c|c|c|c|}
\hline $\begin{array}{l}\text { Hydrological } \\
\text { drought } \\
\text { index } \\
\text { studies }\end{array}$ & \multicolumn{2}{|c|}{$\begin{array}{c}\text { Total number of studies of } \\
\text { drought } \\
\text { indices: } 550\end{array}$} & \multicolumn{2}{|c|}{$\begin{array}{l}\text { Total number of studies } \\
\text { mentioning a country: } \\
344\end{array}$} & $\begin{array}{r}\text { Studies not } \\
\text { mentioning } \\
\text { a country: } \\
37.5 \%\end{array}$ & \multirow[t]{2}{*}{ Top three subject areas } \\
\hline $\begin{array}{l}\text { "Hydrological } \\
\text { drought" indices } \\
\text { mentioned in } \\
\text { the study }\end{array}$ & Acronym & Input data & $\begin{array}{r}\text { Number } \\
\text { of } \\
\text { studies }\end{array}$ & $\begin{array}{r}\text { Studies } \\
\text { mentioning } \\
\text { a country }\end{array}$ & $\begin{array}{r}\text { Portion of } \\
\text { studies not } \\
\text { mentioning a } \\
\text { country (\%) }\end{array}$ & \\
\hline Reservoir level & & $\begin{array}{l}\text { Water levels in } \\
\text { reservoirs }\end{array}$ & 72 & 35 & 51.4 & $\begin{array}{l}\text { (1) Environmental science } \\
\text { (2) Engineering } \\
\text { (3) Earth and planetary } \\
\text { sciences }\end{array}$ \\
\hline $\begin{array}{l}\text { Palmer hydro- } \\
\text { logical drought } \\
\text { index }\end{array}$ & PHDI & $\begin{array}{l}\text { Precipitation, tem- } \\
\text { perature, available } \\
\text { water content }\end{array}$ & 58 & 34 & 41.4 & $\begin{array}{l}\text { (1) Environmental science } \\
\text { (2) Earth and planetary } \\
\text { sciences } \\
\text { (3) Agricultural and biologi- } \\
\text { cal sciences }\end{array}$ \\
\hline $\begin{array}{l}\text { Streamflow } \\
\text { drought index }\end{array}$ & SDI & Streamflow values & 180 & 117 & 35 & $\begin{array}{l}\text { (1) Environmental science } \\
\text { (2) Agricultural and biologi- } \\
\text { cal sciences } \\
\text { (3) Earth and planetary } \\
\text { sciences }\end{array}$ \\
\hline $\begin{array}{l}\text { Standardised } \\
\text { runoff index }\end{array}$ & SRI & "Runoff" & 106 & 69 & 34.9 & $\begin{array}{l}\text { (1) Environmental science } \\
\text { (2) Earth and planetary } \\
\text { sciences } \\
\text { (3) Engineering }\end{array}$ \\
\hline $\begin{array}{l}\text { Standardised } \\
\text { streamflow index }\end{array}$ & SSFI & Streamflow data & 85 & 56 & 34.1 & $\begin{array}{l}\text { (1) Environmental science } \\
\text { (2) Earth and planetary } \\
\text { sciences } \\
\text { (3) Agricultural and biologi- } \\
\text { cal sciences }\end{array}$ \\
\hline $\begin{array}{l}\text { Streamflow } \\
\text { anomaly }\end{array}$ & & Streamflow data & 9 & 8 & 11.1 & $\begin{array}{l}\text { (1) Environmental science } \\
\text { (2) Earth and planetary } \\
\text { sciences } \\
\text { (3) Agricultural and biologi- } \\
\text { cal sciences }\end{array}$ \\
\hline $\begin{array}{l}\text { Standardised } \\
\text { water-level index }\end{array}$ & SWI & $\begin{array}{l}\text { Groundwater well } \\
\text { levels }\end{array}$ & 17 & 13 & 23.5 & $\begin{array}{l}\text { (1) Environmental science } \\
\text { (2) Earth and planetary } \\
\text { sciences } \\
\text { (3) Social sciences }\end{array}$ \\
\hline $\begin{array}{l}\text { Surface water } \\
\text { supply index }\end{array}$ & SWSI & $\begin{array}{l}\text { Reservoir storage, } \\
\text { streamflow, snow- } \\
\text { pack and precipita- } \\
\text { tion }\end{array}$ & 23 & 12 & 47.8 & $\begin{array}{l}\text { (1) Environmental science } \\
\text { (2) Engineering } \\
\text { (3) Social sciences }\end{array}$ \\
\hline
\end{tabular}


Table 1. Continued.

\begin{tabular}{ll|rrrl}
\hline $\begin{array}{l}\text { Drought } \\
\text { impact } \\
\text { studies }\end{array}$ & Input data & $\begin{array}{r}\text { Number } \\
\text { of } \\
\text { studies }\end{array}$ & $\begin{array}{r}\text { Studies } \\
\text { mentioning } \\
\text { a country }\end{array}$ & $\begin{array}{r}\text { Portion of } \\
\text { studies not } \\
\text { mentioning a } \\
\text { country (\%) }\end{array}$ & \\
\hline Food security & $\begin{array}{l}\text { Food security, famine, } \\
\text { hunger, malnourishment, } \\
\text { malnutrition, agricultural } \\
\text { loss }\end{array}$ & 4764 & 2601 & 45.4 & $\begin{array}{l}\text { (1) Agricultural and biological sciences } \\
\text { (2) Environmental science }\end{array}$ \\
\hline Water security & $\begin{array}{l}\text { Water security, water ac- } \\
\text { cess, water availability, } \\
\text { water crisis }\end{array}$ & 805 & 506 & 37.1 & $\begin{array}{l}\text { (1) Environmental science } \\
\text { (2) Social sciences }\end{array}$ \\
\hline
\end{tabular}

returned 4137 articles for the "meteorological" drought type of indices, 2799 articles linked to "agricultural" drought and 393 articles linked to "hydrological" drought. The title, authors, author's keywords, year of publication, journal name and abstract were retrieved using the Bibliometrix package (Aria and Cuccurullo, 2017) executed in R (version 4.0.0) following Addor and Melsen (2019). In the title, keywords and abstract of each paper, names of countries were identified, corresponding to the area of application of the study. The same approach was followed for the drought impacts. We grouped drought impacts into two focus categories: food security and water security. Their keywords are indicated in Table 1. The queries included "drought" AND selected "[drought impact]". This resulted in 4764 articles linking drought to food security and 805 articles linking drought to water security.

All articles were published between 1960 and March 2021 and the exact queries for both drought indices and impacts are included in Table A1. Even though we recognise drought can impact ecosystems, this topic was excluded from the analysis for reasons of brevity. The dataset and the script used for its analysis are both available for consultation (Kchouk et al., 2021).

Many scientific studies are methodological; their goal can be the validation, calibration or improvement of the indices, and thus not all studies have a focus country. We only considered studies mentioning a country in their title, abstract and keywords - this being the only criteria of inclusion or rejection of papers in our analysis. This reduced the number of studies including a name of a country in their title, abstract and keywords by $28 \%$ for drought indices and by $44 \%$ for drought impacts. We also did a manual verification on some of the scientific studies to see if the association with a country was valid. This allowed us to bring some corrections to the metadata to avoid incorrect associations (e.g. removing mentions of the "Indian Ocean" that led to the incorrect association of the studies to India, removing the copyrights, generally at the end of the abstract, referring to another country than the one of the study).

\section{Results}

\subsection{Drought types and indices}

The indices mentioned in the drought-related studies were classified according to the categories used in Table 1; their frequency of occurrence is shown in Fig. 1. Meteorological drought indices are reported most frequently, followed by agricultural or soil moisture drought indices and hydrological drought indices. The most frequently mentioned indicator is the standardised precipitation index (SPI), followed by the normalised difference vegetation index (NDVI). Hydrological drought indices are less frequently utilised in comparison to the two other categories.

For the regions of Australia-Oceania, the Middle East and North Africa (MENA), and sub-Saharan Africa (SSA), there are fewer studies utilising hydrological drought indices than for the other regions (Fig. 2). Further geographical differences are observed from Fig. 2. Most areas resemble the overall pattern shown in Fig. 1; exceptions are AustraliaOceania and sub-Saharan Africa, where agricultural drought indices are most frequently reported.

In addition, not only are meteorological drought indices the most investigated, but they are also the most associated with a country in studies in comparison to agricultural drought, hydrological drought and impacts (Table 1). Meteorological drought indices represent $53 \%$ of the scientific studies, while agricultural drought represents $42 \%$ and hydrological drought only $5 \%$. This indicates that in most of the studies, rainfall and the temperature are the dominant criteria utilised to report the occurrence of drought. Such a result is expected because of the ease of use of meteorological drought indices. We further develop this point in Sect. 4.3.

During the preliminary research that lead to the results mentioned in our study, we conducted a time analysis. We visualised and compared the evolution of the usage of drought indices and drought impacts in the literature in order to analyse and link it to factors such as improved data availability, scientific progress or a change in the societal view on droughts (not shown). However, we did not find any remark- 


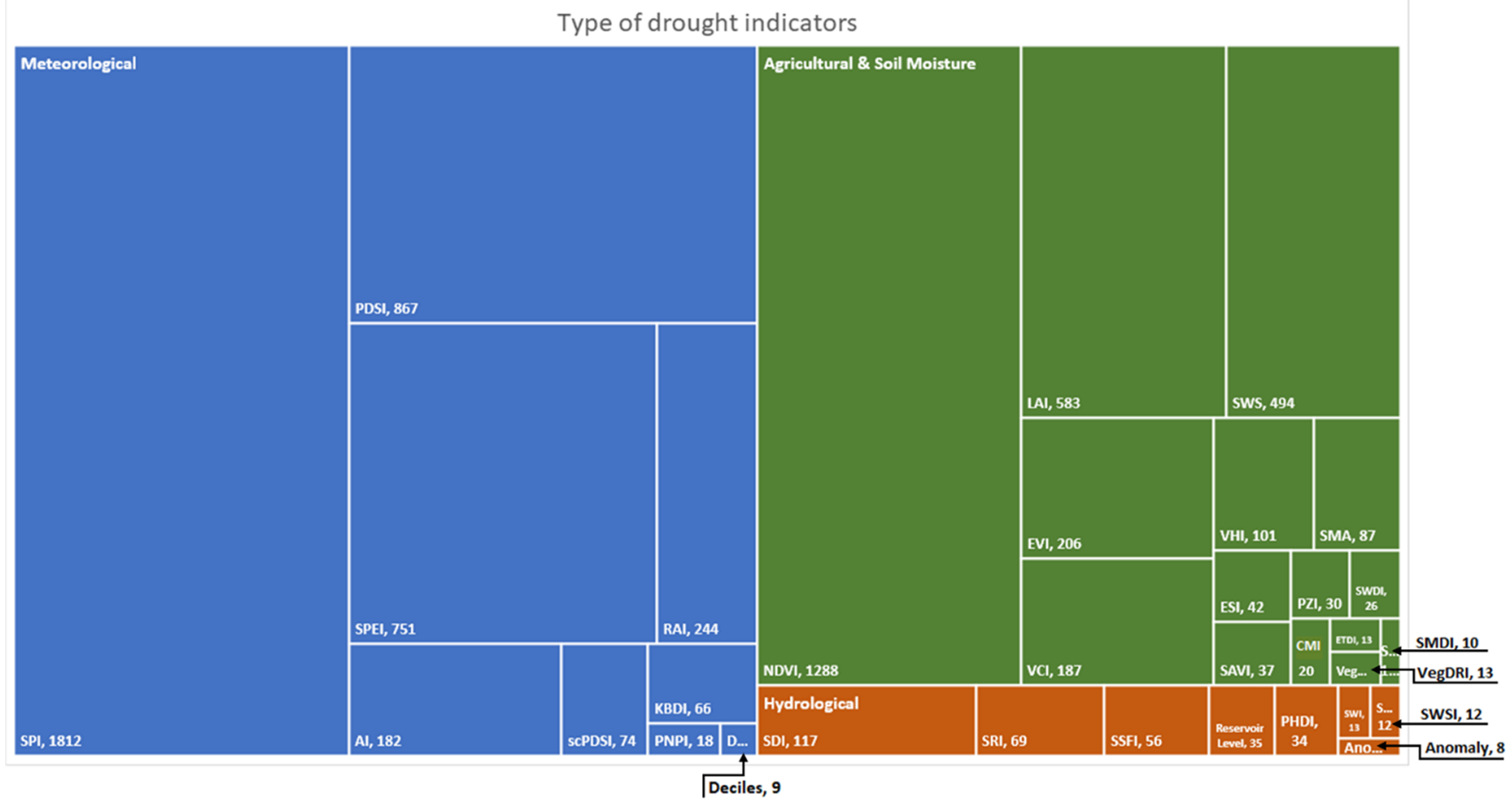

Figure 1. Tree map showing the proportion of indices for different drought types (blue is meteorological, green is agricultural and soil moisture drought, and orange is hydrological drought) employed in the title, abstract and keywords of drought-related studies on Scopus. The number indicates the number of studies including a country in their title, abstract or authors' keywords.

able pattern, peak or correlation. Therefore, we decided to not include this part in our study.

\subsection{Drought-related impacts: food security and water security}

Globally, there were 5 times more studies linking drought to food security than drought to water security (Fig. 3). This pattern is the same for most areas of the world. For subSaharan Africa the predominance of food security indices is most pronounced (93\%), followed by Asia and Europe $(84 \%)$. Australia-Oceania is the only region where droughtrelated water security studies predominate over food security studies (52\%), while sub-Saharan Africa is the region where it is reported the least $(6.6 \%)$.

\subsection{Geographic patterns for indices of drivers and impacts}

Figure 4 shows that drought driver studies are quite evenly distributed across the regions except for SSA. The height of the dark blue boxes is substantially smaller than the others, suggesting that the share of SSA in drought driver studies is minor.

In the same way, two geographical patterns appear in the share of drought-related impact studies. The height of the boxes of SSA and Australia-Oceania for food and water securities, respectively, related to drought is significantly larger than those of the other regions for the same indicator category. This means that food security related to drought is most frequently reported for SSA and that water security related to drought is most frequently reported for Australia-Oceania. Similarly, drought-related water security is least reported for Europe.

The geographical pattern of drought drivers and impact studies seen in Fig. 4 is also present in the cartogram representations in Fig. 5. In this cartogram representation, each country has been rescaled in proportion to the number of studies on Scopus related to drought indices or water and food security impacts. First, the three drought driver categories appear to have the same pattern of investigation: all are mostly focused on northern high-income countries. The United States and Mexico, northern Mediterranean countries, and Australia-Oceania strongly focus on drivers in droughtrelated studies. Middle-income countries with high demographic and economic growth such as China, India and Iran also see a focus on drought-related drivers. They stand out from their geographic neighbours that are almost disappearing from the map.

In contrast, the African continent is strongly underrepresented in terms of drought driver studies, particularly with regard to meteorological and hydrological drought indices, with notable exceptions for Ethiopia, Kenya and South Africa. However, the distribution of agricultural and soil 


\begin{tabular}{|c|c|c|c|}
\hline \multicolumn{4}{|c|}{ Drought Type Indicators } \\
\hline 0 & $25 \%$ & $75 \%$ & $100 \%$ \\
\hline All & $53.6 \%$ & $41.8 \%$ & $4.6 \%$ \\
\hline Asia & $56.7 \%$ & $38.6 \%$ & $4.7 \%$ \\
\hline Australia-Oceania & $44.5 \%$ & $51.8 \%$ & $3.6 \%$ \\
\hline Europe & $52.1 \%$ & $42.8 \%$ & $5.1 \%$ \\
\hline Latin America & $47.7 \%$ & $47.3 \%$ & $5.0 \%$ \\
\hline Middle East and North Africa & $50.6 \%$ & $45.9 \%$ & 3.5\% \\
\hline North America & $53.9 \%$ & $41.4 \%$ & $4.7 \%$ \\
\hline Sub-Saharan Africa & $48.1 \%$ & $49.0 \%$ & 2.8 \\
\hline
\end{tabular}

Figure 2. Bar plot showing the proportion of drought type studies per region of the world, according to the drought indices referred to in the title, abstract and keywords of drought-related studies on Scopus.

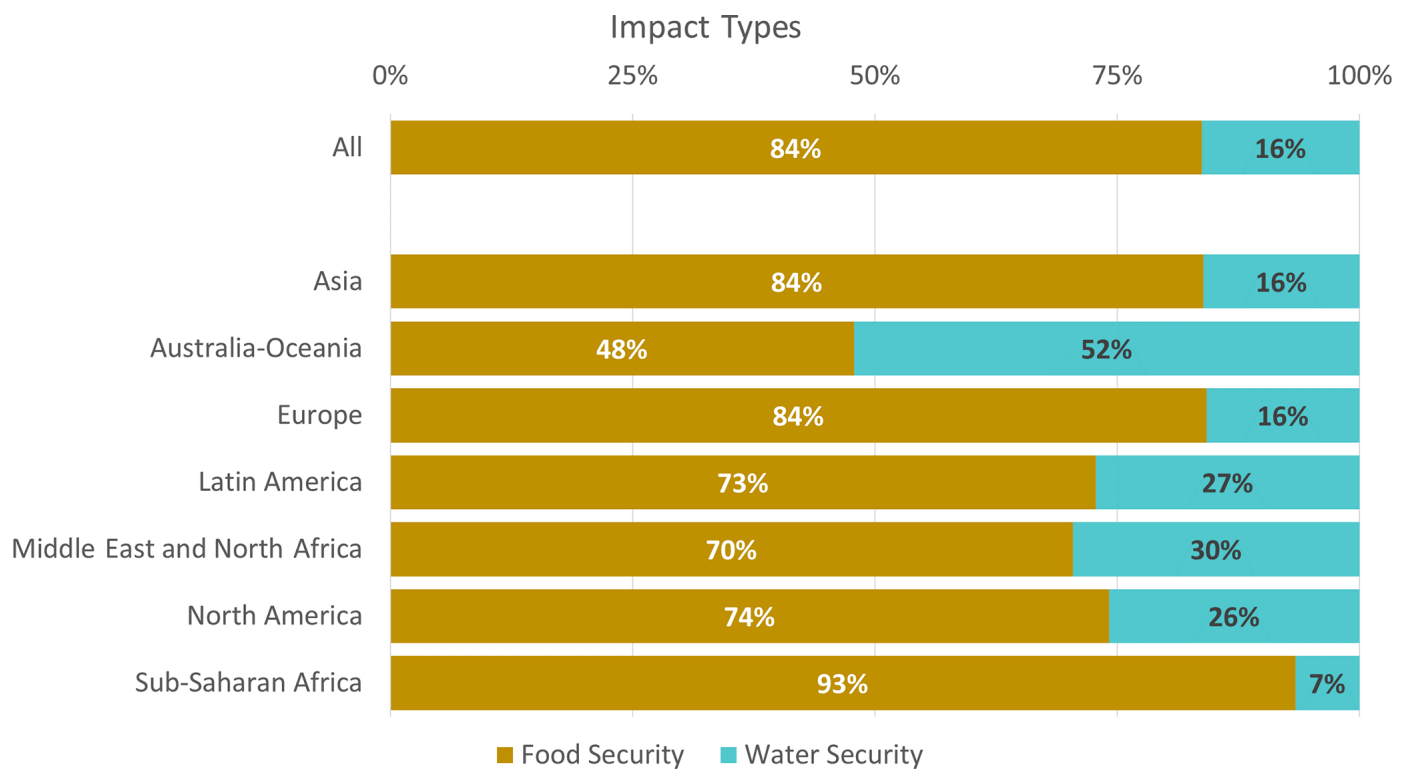

Figure 3. Bar plot showing the proportion of food and water security studies related to drought per region of the world on Scopus.

moisture drought studies appears to be more even in African countries and higher in Sahelian countries.

Looking at the geographical repartition of drought-related impact studies (Fig. 5d and e), two main observations are notable. First, the repartition of the impact studies differs from the driver studies. Second, both impacts, food and water security, show a different geographic pattern. Water security related to drought is most frequently investigated for Australia, the USA and Mexico, Brazil, the Middle East, and South Africa. In contrast, food security is most commonly investigated for India, Ethiopia, Kenya and other African countries.

\section{Discussion}

This bibliometric study shows that unbalanced attention is given to drought drivers and impacts across the world. In this discussion section, we start by raising four hypotheses to explain why some features of drought are more frequently reported for some regions or countries than for others. The four hypotheses relate to physical conditions (Sect. 4.1), socioeconomic conditions (Sect. 4.2), data availability (Sect. 4.3), and scientific interests and orientation (Sect. 4.4). We continue by discussing potential limitations in our methodologi- 


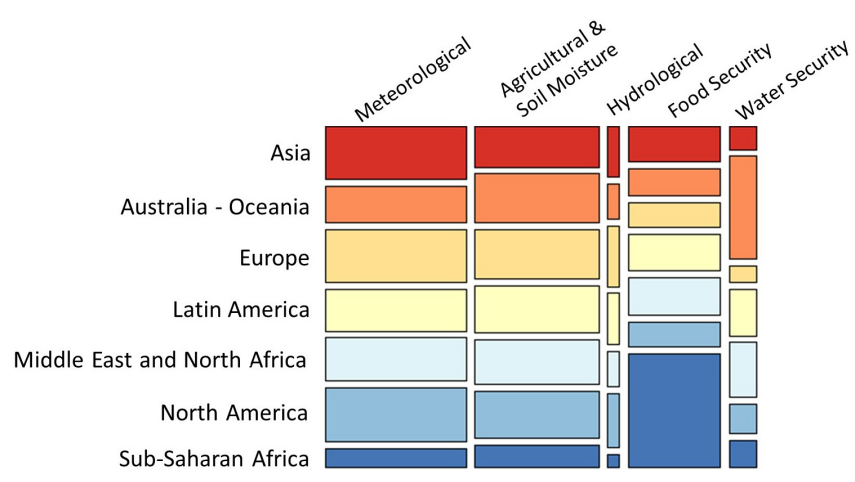

Figure 4. Mosaic plot showing how frequently keywords, being the types of drought and impacts, were mentioned in the titles, abstracts and keywords in drought-related studies on Scopus. The height (vertical) of each box indicates how frequently the keyword is used for each region (the frequency was scaled by the number of papers for each region; that is, the plots show the keyword frequency if all the regions had an equal number of papers). The width (horizontal) of each box indicates the relative frequency of each keyword.

cal approach (Sect. 4.5). We posit that these four hypotheses are also the four dimensions that are inherent to the local context of a geographic area. Drought monitoring is influenced by these to accurately predict droughts, their severity and their impacts. In that sense, we end by formulating recommendations (Sect. 4.6) about shifting the scope of drought metrics to match the local context of a specific drought event.

\subsection{Physical conditions}

The most notable result from Sect. 3 is the more abundant investigation of meteorological drought over agricultural drought and hydrological drought (except in SSA and Australia-Oceania), with the SPI being the most used indicator in drought-related studies.

By focusing on meteorological drought, it is mainly the deficit of precipitation that is investigated. In humid areas, tropical, continental or temperate climates, a deficit of precipitation is less likely to affect the overall physical water scarcity and cause water shortage. In that sense, the occurrence of a drought is only statistically based and does not reflect a true water deficit for the demand, only a below average situation (which is, however, in line with formal definitions of drought). In arid and semi-arid climates with lower levels of precipitation, it is recommended to use SPI cautiously because it can fail to indicate drought occurrence $(\mathrm{Wu}$ et al., 2007) and to opt instead for indices that include evapotranspiration like the SPEI (Salimi et al., 2021). In such areas where evapotranspiration plays a larger role with regard to evaporative demand, water shortage is more common. For arid and semi-arid areas with low average rainfall and a higher risk of water scarcity, it may be more appropriate to determine water deficit at the crop, field or farm scale. This could explain the more frequent use of agricul- tural drought indices in the more arid Australian-Oceania and sub-Saharan regions (Figs. 2 and 4) that mainly monitor vegetation (NDVI, LAI) and soil water content (SWS) (Fig. 1).

For some agricultural drought indices, there is both an upper and a lower limit that is independent of whether the climate of the area is arid or humid: vegetation health or soil water content are or are not frequently deteriorated or in deficit, respectively. In that sense, agricultural drought indices are relevant for any type of climate. However, SPI and most meteorological drought and hydrological drought indices are statistical values showing a deviation from the average and are standardised for all climates. Even if they remain meaningful, drought is more challenging in dry climates rather than wet climates. This key point is dismissed because of the statistical and standardising propensity of meteorological drought and hydrological drought indices in contrast to the values of agricultural drought indices that are a practical interpretation of hydro-climatic features (e.g. of the reflectance, in the case of NDVI and LAI).

\subsection{Socio-economic conditions}

SSA combines the lowest number of studies about drought indices with the highest proportion in terms of drought impacts (Fig. 4). Even though SSA is known to experience a rise in temperatures and an increase in aridity in the past, present and future by observation and model projections (Niang et al., 2014; Serdeczny et al., 2017) the reported impacts in the Emergency Events Database (2021) (EM-DAT) are scarce (Harrington and Otto, 2020). Yet, the EM-DAT run by the Centre for Research on the Epidemiology of Disasters (CRED) has the most complete and global records of past natural and human-made disaster events (Guha-Sapir et al., 2012).

Most of SSA is in a situation of economic water scarcity (Molden, 2013), implying a lack of human, institutional and financial capital to satisfy the demand for water, even in areas where the physical availability of water is not limited. The symptoms described by Molden (2013) associated with economic water scarcity include scant infrastructure development, either small or large scale, meaning that populations experience difficulties obtaining sufficient water to meet agricultural or domestic needs. Applying the same reasoning, drought mitigation or monitoring bodies and scientific publications are a product of human, institutional and financial capital. Thus, it is likely that drought drivers are under-investigated in SSA, leading to the same effects of economic water scarcity: water and food insecurities. Also, the report of impacts of extreme weather in SSA to disaster databases like EM-DATA is predominantly conducted by non-governmental organisations rather than governments, often as a side product of their main task to identify the location with the greatest need for humanitarian aid (Harrington and Otto, 2020). 


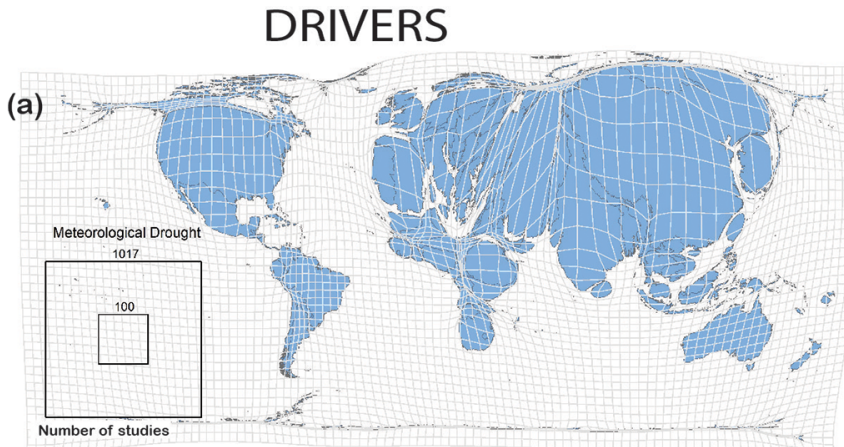

IMPACTS
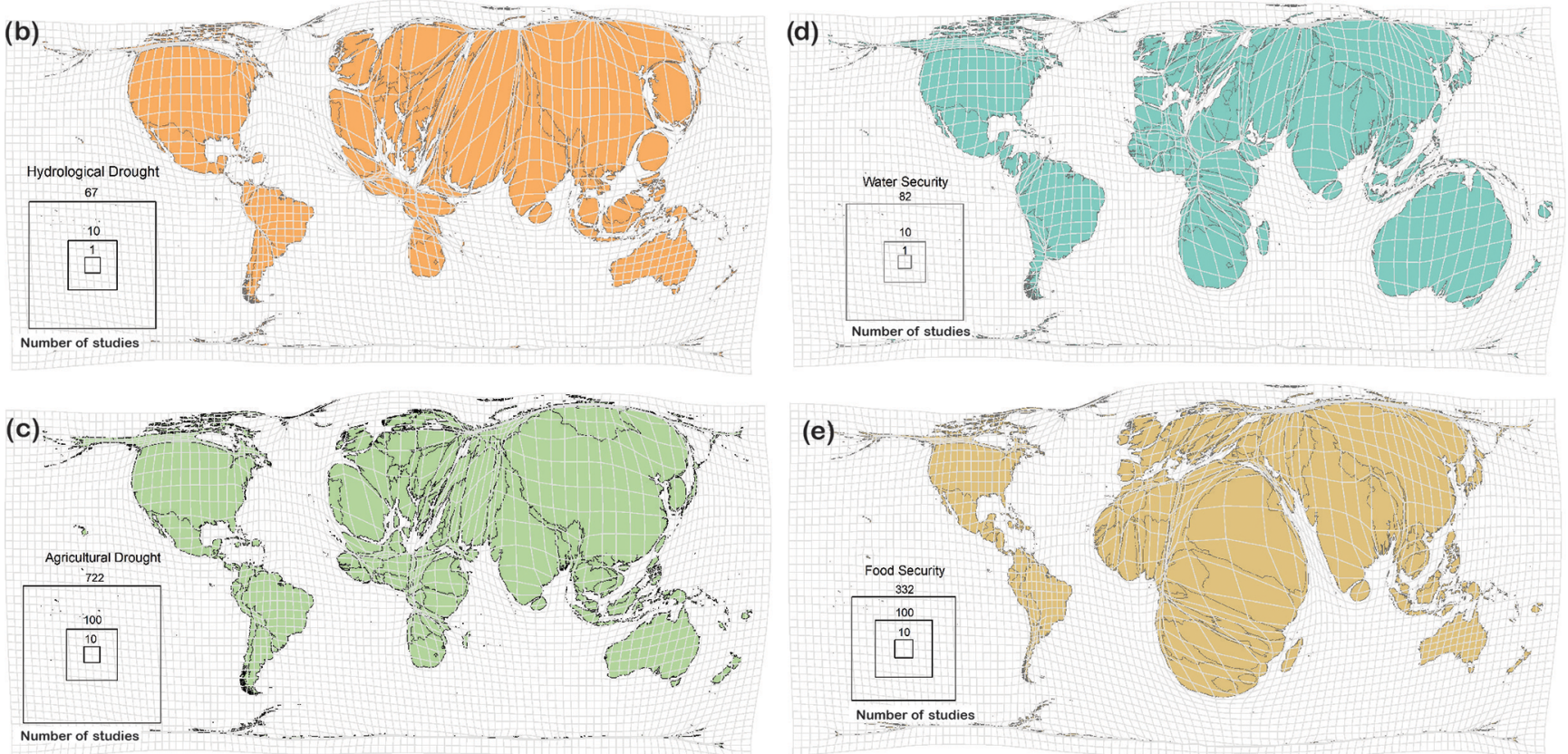

Figure 5. Contiguous cartograms (Gastner-Newman) of the world with each country rescaled in proportion to the number of studies on Scopus related to drought and (a) meteorological drought indices, (b) hydrological drought indices, (c) agricultural and soil moisture drought indices, (d) food security, and (e) water security. The size of the square relates to the size of the countries and indicates the number of studies.

In some areas, food insecurity can be a cumulative result of a dry climate and high pressure on natural resources enhanced by rapid demographic growth. Countries such as Bangladesh, China, Ethiopia, India, Indonesia and Pakistan have some of the highest number of drought-related food security publications (Fig. 5). Most of these countries have high fertility rates and rapid population growth (United Nations, 2019; Vollset et al., 2020). According to the Food and Agriculture Organization (FAO, 2010), the majority of the world's undernourished people live in these six countries, and over $40 \%$ live in China and India alone. The same applies for the countries of SSA, presenting the highest population growth rate in the world (World Bank, 2019), the highest number of drought-related food security publications (Fig. 5) and $22 \%$ of the population being undernourished (FAO et al., 2019). A rapid population growth increases the challenge of adequately meeting nutritional needs as food production de- pends on croplands and water supply, which are under strain as human populations increase. This suggests that countries with arid climates and a high population growth are more exposed to food security impacts.

Moreover, populations of low-income countries are the most exposed to drought-related food insecurity. In the world's poorest countries, around $30 \%$ of GDP (gross domestic product) comes from agriculture; those countries are mostly concentrated around the Sahelian region: Mali (37.4\% of GDP), Niger (35.4\%), Chad (46.1\%), Central African Republic (31.9\%), Sudan (31.2\%), Kenya (31.1\%) and Ethiopia (34.7\%) (World Bank, 2016). As we can see from Fig. 5, those countries are most commonly reporting food security impacts related to drought. In contrast, in OECD (Organisation for Economic Co-operation and Development) economies - regarded as developed and highincome countries - agriculture accounts for less than $1.5 \%$ 
of GDP (World Bank, 2016). In the same way, we note the fewest amount of publications related to food security in those OECD countries. Also, in these Sahelian countries, agriculture accounts for more than $80 \%$ of the livelihoods (FAO, 2021). As more people rely on agriculture for their livelihood, they are more exposed to hazards like drought and thus vulnerable to food-insecurity and the poverty trap.

It is also important to mention the link between food security and governance. Food security is dependent on a complex interplay of factors. Some are outside the direct control of governments, like hydrometeorological extremes. But institutions, rules and political processes do play an important role in reaching increased food security. According to the Food and Agriculture Organization (FAO, 2011), "food security is unlikely to develop where there is not an organised, politically active and mobilised constituency pushing the issue higher on the public and political agenda". Thus, good governance is crucial for reaching food security. Corruption is one of the pervasive aspects of bad governance. It can affect food security by creating inefficiencies in the use of natural resources and food distribution (Economist Intelligence Unit, 2015). Practices of corruption are spread in low-, middle- and high-income countries to different degrees (Transparency International, 2021) and in different levels of the food production and distribution chain (Transparency Int'l, 2019). Lowincome countries are indeed the ones struggling the most to tackle corruption (Transparency International, 2021), contributing to their already prominent exposure to food insecurity. The addition of corruption, an indication of misallocation of resources and incapacity to successfully implement change and development, increases the risk of stagnation of food availability and indicates that those countries are less suitable prospects for successful intervention (Economist Intelligence Unit, 2015).

In other words, focusing on physical drivers of drought is an advantage more apt to be of interest in areas where more basic and essential needs, such as food security, have been met.

\subsection{Data availability}

The SPI is the most widely used index in drought-related studies (Table 1 and Fig. 1). This can be explained by its ease of use. First, it only requires (monthly) precipitation data, easy to monitor by use of rainfall gauge networks or satellite estimation. Second, SPI reference values exist so they can be compared and are applicable in all climate regimes. Finally, SPI can be computed for different periods of time including periods of record containing missing data even though it ideally needs at least 30 years of monthly precipitation data (WMO, 2012).

However, all these strengths are at the same time weaknesses. The SPI will provide in all cases an output whatever inputs are used (Svoboda and Fuchs, 2016). As an example, a significant quantity of zero precipitation values at short timescales may lead to biased values of the SPI because the rainfall might not fit for the recommended gamma distribution, which is a fundamental first step of the SPI calculation (Wu et al., 2007). This scenario is applicable to dry climates with a distinct dry season when calculated for periods shorter than 12 months. As mentioned in Sect. 4.1, an index including an additional temperature parameter to account for evapotranspiration is more suitable for such areas. As we can see in Fig. 6, many countries with dry climates (Iran, Australia and Pakistan) commonly use the SPI in their drought-related studies. In those dry contexts, it has been proposed to focus on the duration of the drought rather than only its severity (Wu et al., 2007). However, even short-lived dry spells often combined with heatwaves of a few days, characteristic of dry climates, when occurring during the reproductive stage of crop development can be enough to ravage an entire harvest leading to food insecurity (Hatfield and Prueger, 2015).

Most of the meteorological drought indices, beyond the SPI, are sensitive to the quantity and reliability of the data to fit the distribution. Their calibration requires a recommended 30 to 50 years of data. However, only very few regions of the world possess such an abundant historical hydrometeorological database. This is particularly challenging for developing countries. According to the World Bank (2018), two thirds of the hydrological observation networks in developing countries are reported to be in poor or declining condition. The distribution of rain gauges across SSA is 8 times lower than the WMO minimum recommended level, and while coastal western and southern Africa and the Eastern Highlands of Kenya and Uganda are relatively well represented, areas of greater aridity are severely underrepresented (Walker et al., 2016). Consequently, reanalysis rainfall products are also less reliable for these more arid regions due to a lack of ground truth data (Walker et al., 2016). The availability of data seems to be closely tied with the socio-economic condition of a country. As mentioned in Sect. 4.2, countries exposed to economic water scarcity generally experience a lack of capital to satisfy the demand for water and a lack of an extensive and well-maintained hydro-climatic monitoring network. Therefore, most of the countries of SSA are underrepresented or absent from publications related to drought indices, while high-income countries commonly report them (Fig. 5).

The same applies for hydrological drought index studies that are under-reported in SSA (Figs. 3, 4 and 5). River flow monitoring networks in SSA are experiencing a similar decline to meteorological monitoring networks (Walker et al., 2016). However, globally, little attention seems to be given to the monitoring of hydrological drought indices (Figs. 1 and 2). Long-term and regular hydrological monitoring is dependent on equipment and installations, their management and maintenance, and the engagement of technical personnel. Not only is hydrological monitoring local and conditional by being directly related to the water supplies, but it requires high costs of implementation not always accessible to low- 


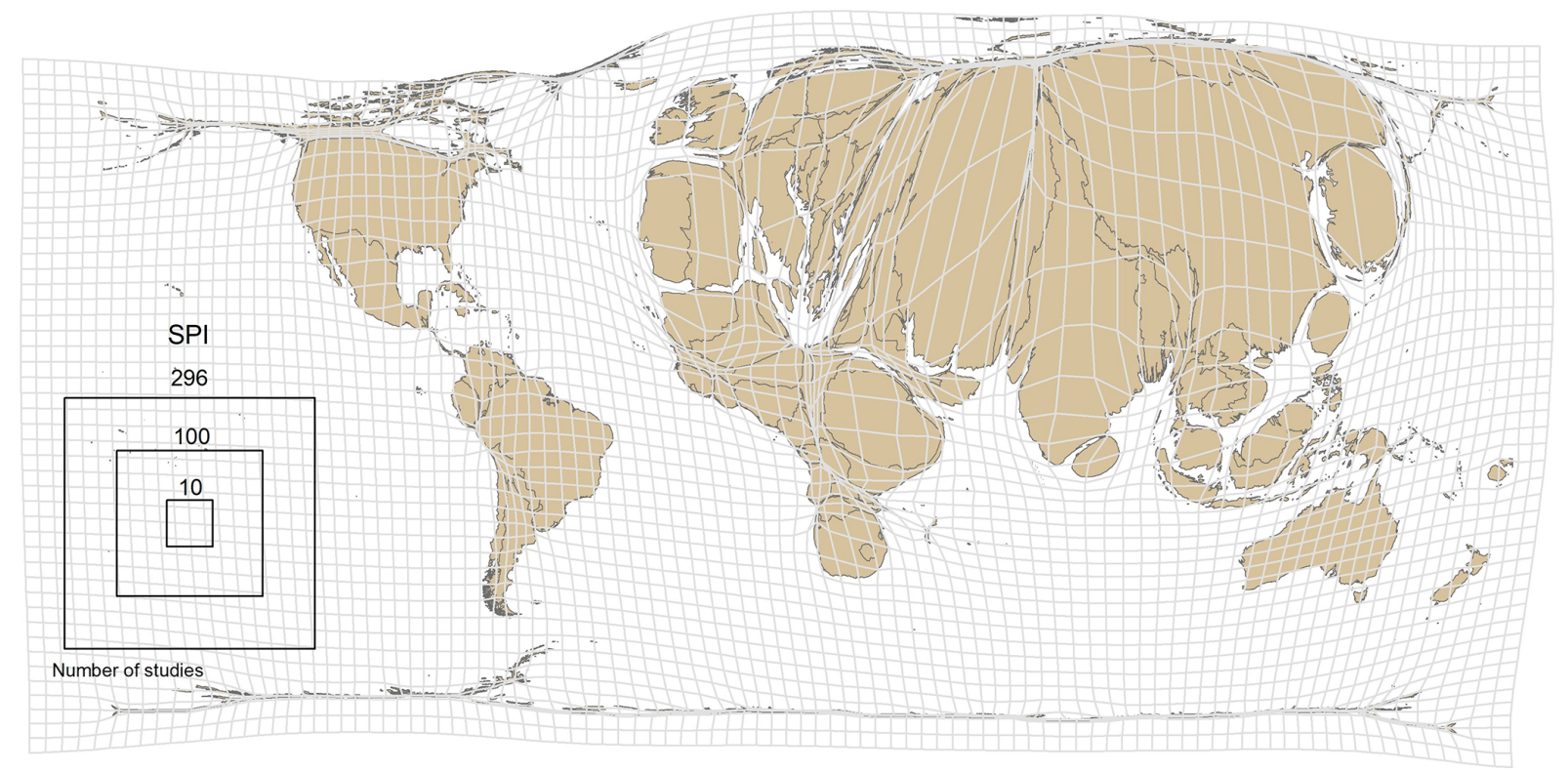

Figure 6. Contiguous cartograms (Gastner-Newman) of the world with each country rescaled in proportion to the number of studies on Scopus related to drought and the SPI.

and middle-income countries. In Europe, the lack of hydrological indices has been attributed more to a lack of a wide access and exchange of hydrometric data at regional, national and international scales due to economic, legal and practical barriers rather than a complete lack of related observations (Bachmair et al., 2016; Viglione et al., 2010).

In the Global North, data sharing is incentivised by funding bodies as an ongoing task alongside research activities. However, as Bezuidenhout and Chakauya (2018) highlight, funders operating in low- and middle-income countries are not fully exploiting this power yet. But the main limitation goes beyond looser requirements or a lack of incentive by funders operating in low- and middle-income countries concerning data sharing. In most African universities, promotion criteria are closely linked to publications of peer-reviewed journal articles (Bezuidenhout et al., 2017). Bezuidenhout and Chakauya (2018) stated that the main, if not only, incentive of researchers of many African universities to disseminate data is to publish it in peer-reviewed journals, which slows down its release rate. In the African continent, these limitations are compounded by questions of network density, data accessibility, temporal continuity, spatial representativeness and tedious bureaucratic processes. These reasons led researchers investigating water resource dynamics in Africa to rely increasingly on modelled and satellite data (Hasan et al., 2019).

As Table 1 shows, NDVI - a remotely sensed index - is the most commonly used in agricultural drought-related studies. Only 3 out of the 15 agricultural drought indices are not remotely sensed. Just like the hydrological drought indices, this can reflect (i) the lack of hydrometric (field) observations or (ii), if they exist, a lack of sharing and access to them (Bachmair et al., 2016). Bachmair et al. (2016) highlight how "the scarcity of water status observations, especially for groundwater, reflects the common focus on drought seen through the lens of rainfall and soil moisture that can be easily (remotely) monitored and/or modelled". Indeed, the data needed to calculate agricultural drought indices seem more accessible. The most used index is the NDVI, and it requires land surface imagery containing both red and infrared bands and a processing software application; global NDVI datasets are available open source at relatively high spatiotemporal distributions. As there are no requirements for historical data for calibration or a monitoring network, this could explain why the African continent more prominently reports agricultural drought than meteorological drought and hydrological drought (Fig. 5).

It is important to realise that data availability may be closely tied to the year of implementation of the drought indices. Indeed, hydro-climatic databases have different ages and dataset quality according to the country, but it can also be possible that the implementation of drought indices is a precursor of hydro-climatic data monitoring.

\subsection{Scientific interest and orientation}

As mentioned previously, in DEWSs, the indices linked to the three categories of drought are seen as drivers as they are used to determine the occurrence and severity of a drought. However, as shown in Sects. 3 and 4.3, the distinction between drought drivers and impacts, based on hydro-climatic variables, is context-dependent. First, the linear representa- 
tion of drought implies that agricultural drought and hydrological drought are an impact of meteorological drought. Yet the indices used for meteorological drought have a different scope to those used for agricultural drought and hydrological drought. Taking the example of the most used indices, the SPI has a temporal focus with a strong statistical perspective on drought, whereas for agricultural drought, the NDVI has a "spatial distribution" focus as it uses remote sensing to indirectly determine water limitation in the vegetation at a specific time, like a snapshot of the vegetation health. In that sense, the NDVI measures a drought's impact.

Moreover, water security is often confounded with hydrological drought. However, as we can see from Fig. 5d and e, the areas where each hydrological drought and water security are reported in scientific studies are not the same, suggesting that the occurrence of the first does not imply the other. In that sense, the literature seemingly indicates that hydrological drought is not the only driver of water security. It is wellestablished that human-driven demand affects water security, along with the hydrologic system (Van Loon et al., 2016a, b).

The scientific reporting about drought suggests its risk of occurrence in an area and potentially an initiative of preparation for related damages. Though for each country, it is likely that drought is investigated according to (i) a determined scientific approach, more physical or social, and (ii) a purpose, in the sense of what is at greatest risk of being impacted by drought.

As shown in Table 1, most of the drought driver indices are investigated under the domain of environmental, Earth and agricultural sciences, suggesting a more physically based approach. Food and water securities related to drought, respectively more reported in SSA and in Australia-Oceania (Fig. 5), are also studied through the scope of physical sciences but unlike the drivers also through the lens of social sciences (Table 1).

Institutional incentives in many western countries may favour research that falls into well-defined silos. Research that meaningfully incorporates both physical and social sciences may not be sufficiently interesting to merit groundbreaking publications on both fronts; it may instead require one or the other discipline serving in a more consultative role.

Food security is a complex concept that requires a holistic approach. Food systems underpin food security, and they are the result of the production, processing, distribution, preparation and consumption of food. These steps are themselves the results of dynamic interactions between and within the biogeophysical and human environments (Gregory et al., 2005). Thus, its study requires the intervention of different specialists. Food systems encompass three main components: "(i) food availability (with elements related to production, distribution and exchange); (ii) food access (with elements related to affordability, allocation and preference) and (iii) food utilisation (with elements related to nutritional value, social value and food safety)" (Gregory et al., 2005). Hence, when food systems are stressed, food security is affected. As food se- curity depends on many components, it stands vulnerable to the disturbance of any of them. These components can be disturbed by a range of factors that can be environmental, like droughts, but also circumstantial, like conflict, changes in international trade agreements and policies, and HIV/AIDS (Gregory et al., 2005). Food insecurity can be aggravated when these factors are combined. SSA is an area particularly prone to extreme heat-related impacts, as we mentioned in Sect. 4.2, but also to these circumstances. SSA holds (i) more than $95 \%$ of farmed land relying on rainfed agriculture (Wani et al., 2009), (ii) about $75 \%$ of the world's HIV/AIDS prevalence as of 2016 (Odugbesan and Rjoub, 2019), and (iii) 19 of the 43 economies with the highest poverty rate, all classified as in fragile and conflict-affected situations (Corral et al., 2020). This indicates that in drought-related studies focused on sub-Saharan Africa, food security and the occurrence of these social processes are closely related.

Australia, known to be the driest inhabited continent (Hill, 2004), has a "National Plan for Water Security" that comprises a variety of mechanisms addressed by national and state governments (Cook and Bakker, 2012). Water security is also aimed to be addressed in an integrative and multiscale way by "taking action on climate change, using water wisely, securing water supplies and supporting healthy rivers and wetlands" (Cook and Bakker, 2012).

Besides Australia, the fact that water security is reported for countries with extreme differences in socio-economics, such as countries in the Sahel and the USA (Fig. 5), suggests the experience of different types of water security. The definition of "water security" by UN Water (2013) is quite holistic. A population's access to adequate quantities of acceptable quality water has the goal to sustain three areas: livelihoods, human well-being and socio-economic development (Montanari et al., 2013). Countries at different stages of development are more likely to focus on one of those three areas. Human well-being related to water security can have many different understandings (Jepson et al., 2017; Hoekstra et al., 2018). Those can vary from one extreme to the other, from enough water for sanitary purposes, e.g. sanitation and showers, to indulgent leisure (e.g. swimming pools and gardens; Savelli et al., 2021; Bradley and Bartram, 2013; Willis et al., 2010). In South Africa, experiences of Cape Town's Day Zero water crisis were diametrically different amongst the wealthy elite and the township dwellers. The first went through restrictions to water their garden and fill up their swimming pools, while the second had insufficient water to take showers and go to the toilet (Savelli et al., 2021). Livelihoods and socio-economic development can also be understood and applied in different ways: from subsistence farming (Makurira et al., 2011) to agrobusiness and irrigation of crops meant for export (e.g. California; Morris and Bucini, 2016). The same can apply to food security: from malnutrition (Belesova et al., 2019) to the genetic adaptation of fruits and vegetable strains to droughts (Basu et al., 2016). 
Therefore, not only can areas be exposed to food and/or water insecurities, but they can be exposed to different declinations and severity within each. Water and food insecurities are very context specific and not even attributable to the country scale but to smaller areas. They are the result of complex and multi-disciplinary mechanisms, including social processes in addition to the physical ones. Thus, to be accurately monitored, drought-related water and food insecurities also need multi-disciplinary metrics. This comes in contradiction to drought indices that measure drought severity by looking only at the hydro-climatic component. Consequently, by eluding (the monitoring of) social processes that can trigger and enhance drought impacts while solely focusing on their hydro-climatic component, DEWSs seem to be formulating an incomplete forecast of the severity of droughts.

\subsection{Limitations}

The inability to deduce a cause-and-effect relationship between two variables solely on the basis of an observed association or correlation between them is common to all disciplines. The same applies to drought drivers and drought impacts even in drought-prone areas. Drought and a related variable such as food security may be directly related, or drought may be one of many stressors in a complex food system. Aligning a drought index and some type of impact variable is a good start, but given the complexity of the systems in question, it is unlikely that drought would have sufficient explanatory or predictive power on its own. Without continuous and widespread monitoring of drought impacts, the societal pattern enabling understanding of how drought is experienced differently and why will not be identified. Therefore, the attempt of explaining the geographical repartition of drought-related impact studies by linking some features of drought to one or many of the four hypotheses detailed above, as per this study, remains then purely hypothetical.

Our approach separated studies by geography, principally at sub-continental scale. Other divisions on which to base our analysis could have been applied, like climatic or income levels, and may have led to additional insights. However, separating studies by geographical region allowed the highlighting of (i) both physical and socio-economic similarities expected in homogenous regions and (ii) countries standing out. This enabled the investigation of potential explanations. Also, certain studies might be missing because they focus on regions rather than countries. We assume that this effect is fairly evenly distributed across the globe, and consequently, we do not expect this to introduce a bias. Besides, for the majority of studies, the country (or countries) that (partly) coincides with the focus region is also mentioned in the title or abstract.

Disparities exist inside countries, particularly larger countries such as the United States, China, Brazil and India, where physical, socio-economic, data availability and interest dis- parities occur. However, because our drought indices and impact investigation and analysis are at the country level, our discussion is also generalised to that scale. Getting rid of that aggregative propensity and grasping those regional disparities would have required an investigation at the scale of within-country regions (e.g. California Central Valley, Brazilian semi-arid region, the city of Cape Town). Yet, it is mostly the name of the countries that are used in publications on Scopus. Moreover, that level of detail and analysis would be more appropriate for comparative studies between chosen semi-arid regions of the world rather than a broader study, like this one, in which a similar focus on drought and drought impact indices is applied.

This study focuses on two types of drought-related impacts: food and water insecurities. Clearly, impacts of droughts are not limited to these two categories. For instance, text mining approaches conducted in Europe, based on media reports, showed that droughts lead to impacts related to forestry, fires, recreation, and the energy and transport sectors in addition to agriculture and water supply (Stahl et al., 2016; de Brito et al., 2020). The geographic distribution of the impact studies would be different if we also had considered impacts on, for instance, energy security, forestry, transport and tourism. Countries with predominant activities related to these sectors may have a high number of related drought impact studies, resulting in a different geographic repartition than the one shown in this present study. Our results are therefore only valid for the impact we evaluated: water and food securities.

The studies we obtained and analysed were a result of using Scopus, rather than another abstract and citation database, and of how we formulated our queries. Our search was constrained to articles having their title, abstract and keywords in English, potentially excluding important articles written in other languages. Additionally, the queries of the drought drivers were per index, individually, while the queries of the impacts were regrouped by two themes. We justified the approach of grouping drought impact keywords due to the lack of metrics existing for water and food insecurities related to drought, as is the case for drought indices.

Also, working with word frequencies, as we did, could have led to the consideration of a drought index or impact that was only mentioned in the abstract as an example but that was not an object of the study. To verify this, we manually evaluated a random sample of 50 studies retrieved from Scopus. We did not identify any study mentioning a drought index while not using or investigating it. Concerning the impacts, we indeed found that sometimes terms like "water security" (or other impacts or the keywords used in the related query detailed in Table A1) were utilised without being investigated in the study. However, for the cases that we encountered in our sample, the studies were global and had a more bibliographical scope. This means that no country was mentioned in the title, abstract or keywords. As mentioned in our methods section, we only considered studies mentioning 
a country in their title, abstract and keywords. This means that there is only a small chance that studies mentioning an impact without further investigating it were included in our analysis. They were generally discarded at an earlier stage because they do not mention any country.

Finally, we chose in our study to focus on how drought drivers and impacts were reflected in the scientific literature. However, disparities between topics of academic research and policy initiatives may exist. In addition, academic research may or may not align with other operational and ground truth initiatives, such as efforts conducted by agencies and organisations working toward drought impact relief, sustainable development and human welfare.

\subsection{Recommendations}

It has to be recognised and highlighted that DEWSs have achieved the goal of providing timely and reliable information to decision makers for drought management and mitigation. As we aimed in our study to put drought-related variables in the appropriate context and appropriate relation to one another, we also acknowledge that the indices that DEWSs rely on are mostly conceptual and descriptive which contradicts DEWS operational purposes. The value of this study is to increase the relevance and utility of DEWSs, which leads us to posit that their structure tends to exclude the human influence on drought and drought influence on humans. The emphasis is on the natural effects on the hydrological system. Subsequently, the accuracy and efficiency of drought mitigation measures can be sub-optimal, based only on information lacking consideration of observed (local) drought impacts.

Several studies have promoted a shift of paradigm, aiming to define drought by its impacts and considering that if a system is impacted by a drought, this means that it was already vulnerable to drought (Blauhut et al., 2015, 2016). Analysing observed and inventoried past drought impacts across European countries was used as proxy to determine specific vulnerabilities. Dealing with drought may benefit from a diagnostic process that starts from analysing drought impacts rather than merely focusing on drivers (Walker, 2022).

We recommend to also consider the human welfare aspects (e.g. food and water securities) that drought is affecting rather than focusing on deficits of water volumes and flows only. In humanitarian approaches, a human welfare approach makes sense as the damages caused by a hazard and that are to be addressed can adversely affect, in the shortand long-term, basic human safety through malnutrition, displacement, and livestock or even human mortality. This approach is also applicable in drought management. Indeed, there is a lack of consensus in defining a drought and its impacts, resulting in difficulty in agreeing on coherent and accurate drought metrics. Therefore, shifting the focus of drought mitigation to observable, graspable and quantifiable goals, such as human welfare, could overcome the uncertainty around drought and drought impact definitions.

The human welfare proxy could be considered as an optimal situation without water shortage, e.g. zero hunger, poverty, conflicts and water insecurity. Thus, it could be aligned with the Sustainable Development Goals (SDGs) as they (i) represent the development priorities of both low- or high-income countries and (ii) benefit from existing and improvable metrics. Also, similarly to drought indices, SDGs have a global nature inclined to overlook the local context. By taking into account local particularities, the SDGs could be reached at the local level even if it is through a drought mitigation scope. Instead of the linear and still conceptual driver-focused meteorological-agriculturalhydrological droughts, the disaster scope could shift to more societally relevant goals linked to poverty, water security and food security. Thus, operational approaches of drought management would be the equivalent of determining the extent to which drought is hampering the achievement of one or many of these defined goals. Therefore, our study calls for additional research analysing the role of drought in research on the Sustainable Development Goals and more precisely about whether or not the DEWSs are incorporated into development efforts by researchers.

Some studies have already been arguing in favour of considering other approaches than the two main top-down and bottom-up approaches for climate change adaptation strategies (Ludwig et al., 2014; Conway et al., 2019). Both approaches come with their strengths and weaknesses, and conciliating them represents a challenge with many complexities often unsuitable for integrating into water management (Ludwig et al., 2014). The issues complicating the decision-making are well known: the top-down approach is too broad and presents too much uncertainty; the bottom-up approach focuses too much on socio-economic vulnerability and too little on developing (technical) solutions (Ludwig et al., 2014). Thus, a risk-oriented approach that focuses more on "systems of receptors rather than conventional sectors" (Warren et al., 2018), in which research identifies vulnerability to different extreme events rather than only analysing their probabilities of occurrence (Bliss and Bowe, 2011), is an alternative.

\section{Conclusions}

We conducted a bibliometric analysis on $5000+$ scientific studies in which drought was associated with an index and water and food securities, with the aim of comparing how drought drivers (e.g. precipitation, temperature, evaporative demand) and drought impacts (food and water insecurities) were reflected in the literature. Our results revealed that drought is mainly depicted through a focus on precipitationbased and remotely sensed indices. It is the SPI, a singlevariable index, that is the most broadly used in different cli- 
matic and geographic contexts despite being the one including the least local contextual information. Drought is regularly approached merely as a rainfall statistical anomaly and equated to meteorological drought.

Drought driver studies tend to focus on particular geographical regions, especially northern countries, whereas studies reporting impacts related to food and water securities are more commonly located in sub-Saharan Africa and Australia-Oceania, respectively. Moreover, the areas where drought drivers are reported in scientific studies are different from the drought impact ones. There is also a difference in the geographic repartition of drought-related food security and water security scientific studies. This suggests that drought-impact studies are certainly dependent on both the physical and human processes occurring in the geographic area, i.e. the local context.

Because "local context" can have different meanings, we raised four hypotheses that can be attributed to local context and that can contribute to drought drivers resulting in drought impacts. First is the physical availability of water; drought driver indices measure the water deficit in one or several of the components of the hydrological cycle, implying that the severity of drought is the same in arid or humid climates. Second is the socio-economic conditions in the countries, like the income per capita and the demography that affect, respectively, the capital involved in research and the vulnerability to hazards. Third, the data availability, related to the second point concerning socio-economic conditions, affects the selection and accuracy of an index, especially if the chosen index is unsuitable for the particular climate. Fourth is the scientific approach and the interest in the country that determines from which physical and/or social science scope drought will be looked at and for what purpose. It seems that drought impacts are considered more through social sciences lenses than drought drivers. Drought driver indices seem to remain conceptual metrics depicting climate features and do not seem to be linked to human-centred solutions. Also, both water and food securities are scientific concerns mostly in arid and semi-arid regions, from high to low income, and whether drought drivers are investigated or not. This suggests many variants of the same type of impact according to what or who is likely to be most impacted by drought in the area.

Thus, more research is needed in which the scope of drought mitigation is widened to the vulnerability to drought events rather than only their probability of occurrence. DEWSs would then more accurately predict the severity of a drought by also including drought indices that are peoplecentred. In this way, drought metrics would also better align with SDGs. These drought metrics could become more useful in monitoring the negative role of drought in achieving human welfare and, with that, the SDGs. 


\section{Appendix A}

Table A1. Table of queries used in the advanced search of Scopus to retrieve the scientific studies of the drought indices and impacts. "M/A/H" signifies meteorological, agricultural and hydrological.

\begin{tabular}{|c|c|c|}
\hline $\begin{array}{l}\text { "M/A/H drought" indices } \\
\text { mentioned in the study }\end{array}$ & Acronym & Query \\
\hline $\begin{array}{l}\text { Standardised precipitation } \\
\text { index }\end{array}$ & SPI & $\begin{array}{l}\text { TITLE-ABS-KEY ( ( "Drought” ) AND ( “SPI” OR “Standardized Precipitation In- } \\
\text { dex") ) }\end{array}$ \\
\hline $\begin{array}{l}\text { Standardised precipitation } \\
\text { evapotranspiration index }\end{array}$ & SPEI & $\begin{array}{l}\text { TITLE-ABS-KEY ( ( "Drought") AND ( "SPEI" OR "Standardized Evapotranspiration } \\
\text { Precipitation Index") ) }\end{array}$ \\
\hline Aridity index & AI & TITLE-ABS-KEY ( ( “Drought”) AND ( “Aridity Index” ) ) \\
\hline Precipitation deciles & Deciles & $\begin{array}{l}\text { TITLE-ABS-KEY ( ( "Drought" ) AND ( "Precipitation Decile*" OR "Rain } \\
\text { decile*" OR "rainfall decile*") ) }\end{array}$ \\
\hline $\begin{array}{l}\text { Keetch-Byram drought } \\
\text { index }\end{array}$ & KBDI & TITLE-ABS-KEY ( ( "Drought”) AND ( "Keetch-Byram Drought Index" OR “KBDI”)) \\
\hline $\begin{array}{l}\text { Palmer drought severity } \\
\text { index }\end{array}$ & PDSI & $\begin{array}{l}\text { TITLE-ABS-KEY ( ( "Drought" ) AND ( "Palmer Drought Severity Index" OR } \\
\text { "PDSI") ) }\end{array}$ \\
\hline $\begin{array}{l}\text { Percent of normal precipita- } \\
\text { tion (index) }\end{array}$ & PNPI & $\begin{array}{l}\text { TITLE-ABS-KEY ( ( "Drought") AND ( "Percent of Normal Precipitation" OR "Percent } \\
\text { of Normal Precipitation Index" OR "PNPI" ) ) }\end{array}$ \\
\hline Rainfall anomaly index & RAI & $\begin{array}{l}\text { TITLE-ABS-KEY ( ( "Drought") AND ( "Rainfall Anomaly Index" OR "Rainfall } \\
\text { Anomaly" OR "RAI" ) ) }\end{array}$ \\
\hline $\begin{array}{l}\text { Self-calibrated Palmer } \\
\text { drought severity index }\end{array}$ & scPDSI & $\begin{array}{l}\text { TITLE-ABS-KEY ( ( "Drought” ) AND ( "Self-Calibrated Palmer Drought Severity In- } \\
\text { dex" OR “sc-PDSI”) ) }\end{array}$ \\
\hline Crop moisture index & CMI & TITLE-ABS-KEY ( ( "Drought”) AND ( “Crop Moisture index” OR “CMI” )) \\
\hline Evaporative stress index & ESI & TITLE-ABS-KEY ( ( “Drought”) AND ( “Evaporative Stress Index” OR “ESI”)) \\
\hline $\begin{array}{l}\text { Evapotranspiration deficit } \\
\text { index }\end{array}$ & ETDI & $\begin{array}{l}\text { TITLE-ABS-KEY ( ( "Drought" ) AND ( "Evapotranspiration Deficit Index" OR } \\
\text { "ETDI")) }\end{array}$ \\
\hline Enhanced vegetation index & EVI & TITLE-ABS-KEY ( ( "Drought”) AND ( "Enhanced Vegetation Index" OR “EVI”)) \\
\hline $\begin{array}{l}\text { Normalised difference vege- } \\
\text { tation index }\end{array}$ & NDVI & $\begin{array}{l}\text { TITLE-ABS-KEY ( ( “Drought”) AND (“Normalized Difference Vegetation Index” OR } \\
\text { "NDVI”)) }\end{array}$ \\
\hline Leaf area index & LAI & TITLE-ABS-KEY ( ( "Drought”) AND ( “Leaf Area Index” OR “LAI”)) \\
\hline $\begin{array}{l}\text { Palmer moisture anomaly } \\
\text { index - known as the Palmer } \\
\mathrm{Z} \text { index }\end{array}$ & PZI & $\begin{array}{l}\text { TITLE-ABS-KEY ( ( "Drought”) AND ( "Palmer Z Index" OR "Palmer Moisture } \\
\text { Anomaly Index" OR "PZI") ) }\end{array}$ \\
\hline $\begin{array}{l}\text { Soil adjusted vegetation in- } \\
\text { dex }\end{array}$ & SAVI & $\begin{array}{l}\text { TITLE-ABS-KEY ( ( "Drought" ) AND ( "Soil Adjusted Vegetation Index" OR } \\
\text { "SAVI") ) }\end{array}$ \\
\hline Soil Moisture Anomaly & SMA & TITLE-ABS-KEY (( “Drought”) AND ( “Soil Moisture Anomaly” OR “SMA”)) \\
\hline Soil moisture deficit index & SMDI & TITLE-ABS-KEY ( ( "Drought”) AND ( "Soil Moisture Deficit Index” OR “SMDI”) ) \\
\hline Soil water deficit index & SWDI & TITLE-ABS-KEY ( ( "Drought”) AND ( “Soil Water Deficit Index” OR “SWDI” ) ) \\
\hline Soil water storage & SWS & TITLE-ABS-KEY ( ( “Drought”) AND ( “Soil Water Storage” OR “SWS” ) ) \\
\hline Vegetation condition index & VCI & TITLE-ABS-KEY ( ( "Drought”) AND ( "Vegetation Condition Index” OR “VCI”) ) \\
\hline $\begin{array}{l}\text { Vegetation drought } \\
\text { response index }\end{array}$ & VegDRI & $\begin{array}{l}\text { TITLE-ABS-KEY ( ( "Drought" ) AND ( "Vegetation Drought Response Index" OR } \\
\text { "VegDRI" OR "Veg DRI") ) }\end{array}$ \\
\hline Vegetation health index & VHI & TITLE-ABS-KEY ( ( "Drought”) AND ( "Vegetation Health Index" OR “VHI” ) ) \\
\hline
\end{tabular}


Table A1. Continued.

\begin{tabular}{|c|c|c|}
\hline $\begin{array}{l}\text { "M/A/H drought" indices } \\
\text { mentioned in the study }\end{array}$ & Acronym & Query \\
\hline Reservoir level & & $\begin{array}{l}\text { TITLE-ABS-KEY ( ( "Drought" ) AND ( "Reservoir level*" OR “water level in reser- } \\
\text { voir" OR "water levels in reservoirs") ) }\end{array}$ \\
\hline $\begin{array}{l}\text { Palmer hydrological } \\
\text { drought index (PHDI) }\end{array}$ & PHDI & $\begin{array}{l}\text { TITLE-ABS-KEY ( ( "Drought” ) AND ( “Palmer Hydrological Drought Index" OR } \\
\text { "PHDI”) ) }\end{array}$ \\
\hline Streamflow drought index & SDI & TITLE-ABS-KEY ( ( "Drought” ) AND ( “Streamflow Drought Index” OR “SDI” ) ) \\
\hline Standardised runoff index & SRI & TITLE-ABS-KEY ( ( "Drought”) AND ( “Standardized Runoff Index” ) ) \\
\hline $\begin{array}{l}\text { Standardised streamflow } \\
\text { index }\end{array}$ & SSFI & $\begin{array}{l}\text { TITLE-ABS-KEY ( ( "Drought” ) AND ( “Standardized Streamflow Index” OR } \\
\text { "SSFI") ) }\end{array}$ \\
\hline Streamflow anomaly & & TITLE-ABS-KEY ( ( “Drought”) AND ( “streamflow anomaly” ) ) \\
\hline $\begin{array}{l}\text { Standardised water-level } \\
\text { index }\end{array}$ & SWI & $\begin{array}{l}\text { TITLE-ABS-KEY ( ( "Drought”) AND ( "Standardized Water Level Index" OR } \\
\text { "SWLI") ) }\end{array}$ \\
\hline Surface water supply index & SWSI & TITLE-ABS-KEY ( ( "Drought” ) AND ( "Surface Water Supply Index” OR “SWSI” ) ) \\
\hline \multicolumn{3}{|l|}{ Drought impacts studies } \\
\hline Food security & \multicolumn{2}{|c|}{ 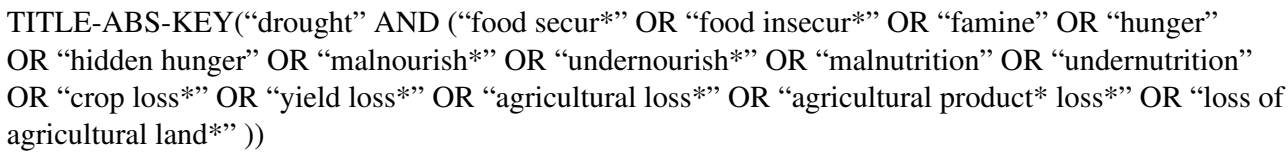 } \\
\hline Water security & \multicolumn{2}{|c|}{ 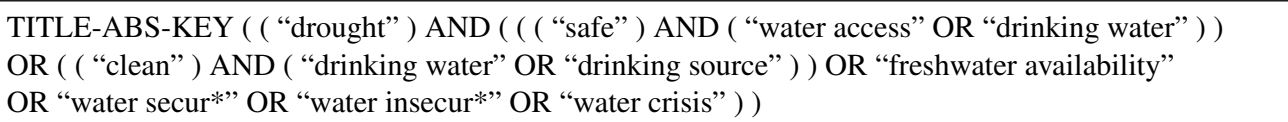 } \\
\hline
\end{tabular}

Code and data availability. Both code and data are available in the 4tu.ResearchData platform. The DOI and link of access is https://doi.org/10.4121/14452845.v2 (Kchouk, 2021).

Author contributions. SK has designed and conducted the research in collaboration with DWW, supervised by LAM and PRvO. SK has written the manuscript with input from all co-authors. The final version has been approved by all co-authors.

Competing interests. The contact author has declared that neither they nor their co-authors have any competing interests.

Disclaimer. Publisher's note: Copernicus Publications remains neutral with regard to jurisdictional claims in published maps and institutional affiliations.
Special issue statement. This article is part of the special issue "Drought vulnerability, risk, and impact assessments: bridging the science-policy gap". It is a result of the EGU General Assembly 2020, 3-8 May 2020.

Acknowledgements. We thank Germano Gondim Ribeiro Neto, Louise Cavalcante de Souza Cabral, Petra Hellegers and Eduardo Sávio Passos Rodrigues Martins who reviewed and provided helpful comments on earlier drafts of the manuscript.

We thank the four reviewers whose comments and suggestions helped improve and clarify this paper.

Financial support. This research has been supported by the Dutch Research Council (NWO) and the Interdisciplinary Research and Education Fund (INREF) of Wageningen University, the Netherlands (grant no. W07.30318.016).

Review statement. This paper was edited by Joaquim G. Pinto and reviewed by Frank Kaspar and three anonymous referees. 


\section{References}

Addor, N. and Melsen, L. A.: Legacy, Rather Than Adequacy, Drives the Selection of Hydrological Models, Water Resour. Res., 55, 378-390, https://doi.org/10.1029/2018wr022958, 2019.

Aria, M. and Cuccurullo, C.: bibliometrix: An R-tool for comprehensive science mapping analysis, J. Informetr., 11, 959-975, 2017.

Bachmair, S., Stahl, K., Collins, K., Hannaford, J., Acreman, M., Svoboda, M., Knutson, C., Smith, K. H., Wall, N., Fuchs, B., Crossman, N. D., and Overton, I. C.: Drought indicators revisited: the need for a wider consideration of environment and society, WIRES Water, 3, 516-536, https://doi.org/10.1002/wat2.1154, 2016.

Basu, S., Ramegowda, V., Kumar, A., and Pereira, A.: Plant adaptation to drought stress, F1000Res, 5, F1000 Faculty Rev-1554, https://doi.org/10.12688/f1000research.7678.1, 2016.

Belesova, K., Agabiirwe, C. N., Zou, M., Phalkey, R., and Wilkinson, P.: Drought exposure as a risk factor for child undernutrition in low-and middle-income countries: A systematic review and assessment of empirical evidence, Environ. Int., 131, 104973, https://doi.org/10.1016/j.envint.2019.104973, 2019.

Bezuidenhout, L. and Chakauya, E.: Hidden concerns of sharing research data by low/middle-income country scientists, Global Bioethics, 29, 39-54, https://doi.org/10.1080/11287462.2018.1441780, 2018.

Bezuidenhout, L. M., Leonelli, S., Kelly, A. H., and Rappert, B.: Beyond the digital divide: Towards a situated approach to open data, Sci. Publ. Policy, 44, 464-475, https://doi.org/10.1093/scipol/scw036, 2017. Louise M. Bezuidenhout, Sabina Leonelli, Ann H. Kelly, Brian Rappert, Beyond the digital divide: Towards a situated approach to open data, Science and Public Policy, Volume 44, Issue 4, August 2017, Pages

Blauhut, V., Gudmundsson, L., and Stahl, K.: Towards panEuropean drought risk maps: quantifying the link between drought indices and reported drought impacts, Environ. Res. Lett., 10, 014008, https://doi.org/10.1088/17489326/10/1/014008, 2015.

Blauhut, V., Stahl, K., Stagge, J. H., Tallaksen, L. M., De Stefano, L., and Vogt, J.: Estimating drought risk across Europe from reported drought impacts, drought indices, and vulnerability factors, Hydrol. Earth Syst. Sci., 20, 2779-2800, https://doi.org/10.5194/hess-20-2779-2016, 2016.

Bliss, K. E. and Bowe, K. F.: Bridging Knowledge Gaps in Water Management: Integrating Approaches to Food, Water, Energy, and the Environment, Center for Strategic and International Studies, ISBN 978-0-89206-646-9, 2011.

Bradley, D. J. and Bartram, J. K.: Domestic water and sanitation as water security: monitoring, concepts and strategy, Philos. T. Roy. Soc. A, 371, 20120420, https://doi.org/10.1098/rsta.2012.0420, 2013.

Brazilian Drought Monitor: https://monitordesecas.ana.gov.br/ mapa?mes=3\&ano=2021, last access: 26 April 2021.

Conway, D., Nicholls, R. J., Brown, S., Tebboth, M. G. L., Adger, W. N., Ahmad, B., Biemans, H., Crick, F., Lutz, A. F., De Campos, R. S., Said, M., Singh, C., Zaroug, M. A. H., Ludi, E., New, M., and Wester, P.: The need for bottom-up assessments of climate risks and adaptation in climate-sensitive regions, Nature
Clim. Change, 9, 503-511, https://doi.org/10.1038/s41558-0190502-0, 2019.

Cook, C. and Bakker, K.: Water security: Debating an emerging paradigm, Global Environ. Chang., 22, 94-102, https://doi.org/10.1016/j.gloenvcha.2011.10.011, 2012.

Corral, P., Irwin, A., Krishnan, N., Mahler, D. G., and Vishwanath, T.: Fragility and Conflict: On the Front Lines of the Fight against Poverty, The World Bank, Washington, DC, https://doi.org/10.1596/978-1-4648-1540-9, 2020.

de Brito, M. M., Kuhlicke, C., and Marx, A.: Near-real-time drought impact assessment: a text mining approach on the 2018/19 drought in Germany, Environ. Res. Lett., 15, 1040a1049, https://doi.org/10.1088/1748-9326/aba4ca, 2020.

Economist Intelligence Unit: Global food security index 2015: An annual measure of the state of global food security, Economist Intelligence Unit, 2015.

Emergency Events Database: http://www.emdat.be/, last access: 31 March 2021.

FAO: The state of food insecurity in the World 2010, Addressing food insecurity in protracted crises, WFP, FAO, J. Rural Stud., 29, 101-112, 2010.

FAO: Good food security governance: the crucial premise to the twin-track approach, Background paper, available at: https://www.fao.org/fileadmin/templates/righttofood/ documents/other_documents/2011_good_food_security_gov/ FoodSecurityGovernanceWorkshop_backgroundpaper.pdf (last access: 13 October 2021), 2011

FAO, IFAD, UNICEF, WFP, and WHO.: The state of food security and nutrition in the world 2019: safeguarding against economic slowdowns and downturns, FAO, Rome, Italy, ISBN 978-92-5131570-5, 2019.

Food and Agriculture Organization (FAO): Country fact sheet on food and agriculture policy trends: available at: http://www.fao. org/in-action/fapda/publications/country-fact-sheets/en/, last access: 26 April 2021.

Gregory, P. J., Ingram, J. S. I., and Brklacich, M.: Climate change and food security, Philos. T. Roy. Soc. B, 360, 2139-2148, https://doi.org/10.1098/rstb.2005.1745, 2005.

Guha-Sapir, D., Vos, F., and Below, R.: Annual Disaster Statistical Review 2010: The Numbers and Trends, Center for Research on the Epidemiology of Disasters (CRED), Université catholique de Louvain, Brussels, Belgium, 42 pp., 2011.

Harrington, L. J. and Otto, F. E. L.: Reconciling theory with the reality of African heatwaves, Nat. Clim. Chang., 10, 796-798, https://doi.org/10.1038/s41558-020-0851-8, 2020.

Hasan, E., Tarhule, A., Zume, J. T., and Kirstetter, P.-E.: +50 Years of Terrestrial Hydroclimatic Variability in Africa's Transboundary Waters, Sci. Rep., 9, 12327, https://doi.org/10.1038/s41598019-48813-x, 2019.

Hatfield, J. L. and Prueger, J. H.: Temperature extremes: Effect on plant growth and development, Weather and Climate Extremes, 10, 4-10, https://doi.org/10.1016/j.wace.2015.08.001, 2015.

Hill, R. S.: Origins of the southeastern Australian vegetation, Philos. T. Roy. Soc. B, 359, 1537-1549, 2004.

Hoekstra, A. Y., Buurman, J., and van Ginkel, K. C. H.: Urban water security: A review, Environ. Res. Lett., 13, 053002, https://doi.org/10.1088/1748-9326/aaba52, 2018.

Jepson, W., Budds, J., Eichelberger, L., Harris, L., Norman, E., O'Reilly, K., Pearson, A., Shah, S., Shinn, J., and Staddon, C.: 
Advancing human capabilities for water security: A relational approach, Water Security, 1, 46-52, 2017.

Kchouk, S., Melsen, L. A., and van Oel, P. R.: Data underlying the publication : "A review of drought indices: predominance of drivers over impacts and the importance of local context", Water Resources Management Group [data set] [code], edited by: Wageningen University and Research, https://doi.org/10.4121/14452845.v2, 2021.

Kim, S., Shao, W., and Kam, J.: Spatiotemporal patterns of US drought awareness, Palgrave Communications, 5, 107, https://doi.org/10.1057/s41599-019-0317-7, 2019.

Knutson, C., Hayes, M., and Phillips, T.: How to reduce drought risk, Drought Mitigation Center Faculty Publications, 168, available at: https://digitalcommons.unl.edu/droughtfacpub/168 (last access: 21 May 2021), 1998.

Lloyd-Hughes, B.: The impracticality of a universal drought definition, Theor. Appl. Climatol., 117, 607-611, 2014.

Logar, I. and Van den Bergh, J.: Methods to assess costs of drought damages and policies for drought mitigation and adaptation: review and recommendations, Water Resour. Manage., 27, 17071720, 10.1007/s11269-012-0119-9, 2011.

Ludwig, F., van Slobbe, E., and Cofino, W.: Climate change adaptation and Integrated Water Resource Management in the water sector, J. Hydrol., 518, 235-242, https://doi.org/10.1016/j.jhydrol.2013.08.010, 2014.

Makurira, H., Savenije, H. H. G., Uhlenbrook, S., Rockström, J., and Senzanje, A.: The effect of system innovations on water productivity in subsistence rainfed agricultural systems in semi-arid Tanzania, Agr. Water Manage., 98, 1696-1703, https://doi.org/10.1016/j.agwat.2011.05.003, 2011.

Mishra, A. K. and Singh, V. P.: A review of drought concepts, J. Hydrol., 391, 202-216, 2010.

Molden, D.: Water for food water for life: A Comprehensive assessment of water management in agriculture, Water for Food Water for Life: A Comprehensive Assessment of Water Management in Agriculture, Taylor and Francis, Green Open Access, 1-645, https://doi.org/10.4324/9781849773799, ISBN 978-1849773799, 2013.

Montanari, A., Young, G., Savenije, H. H. G., Hughes, D., Wagener, T., Ren, L. L., Koutsoyiannis, D., Cudennec, C., Toth, E., Grimaldi, S., Blöschl, G., Sivapalan, M., Beven, K., Gupta, H., Hipsey, M., Schaefli, B., Arheimer, B., Boegh, E., Schymanski, S. J., Di Baldassarre, G., Yu, B., Hubert, P., Huang, Y., Schumann, A., Post, D. A., Srinivasan, V., Harman, C., Thompson, S., Rogger, M., Viglione, A., McMillan, H., Characklis, G., Pang, Z., and Belyaev, V.: "Panta Rhei-Everything Flows": Change in hydrology and society-The IAHS Scientific Decade 2013-2022, Hydrolog. Sci. J., 58, 1256-1275, https://doi.org/10.1080/02626667.2013.809088, 2013.

Morris, K. S. and Bucini, G.: California's drought as opportunity: Redesigning U.S. agriculture for a changing climate, Elementa: Science of the Anthropocene, 4, 000142, https://doi.org/10.12952/journal.elementa.000142, 2016.

Niang, I., Ruppel, O. C., Abdrabo, M. A., Essel, C., Lennard, C., Padgham, J., Urquhart, P., and Descheemaeker, K. K. E.: Africa, in: Climate Change 2014 - Impacts, Adaptation and Vulnerability: Part B: Regional Aspects, Working Group II Contribution to the IPCC Fifth Assessment Report, Volume 2, Regional Aspects, edited by: Intergovernmental Panel on Climate Change, Cam- bridge University Press, 1st edition, Cambridge, 1199-1266, ISBN 9781107683860, 2014.

Odugbesan, J. A. and Rjoub, H.: Relationship among HIV/AIDS Prevalence, Human Capital, Good Governance, and Sustainable Development: Empirical Evidence from Sub-Saharan Africa, Sustainability, 11, 1348, https://doi.org/10.3390/su11051348, 2019.

Princeton Flood and Drought Monitors: http://stream.princeton. edu/, last access: 26 April 2021.

Salimi, H., Asadi, E., and Darbandi, S.: Meteorological and hydrological drought monitoring using several drought indices, Applied Water Science, 11, 11, https://doi.org/10.1007/s13201-02001345-6, 2021.

Santos Pereira, L., Cordery, I., and Iacovides, I.: Water Scarcity Concepts, in: Coping with Water Scarcity: Addressing the Challenges, Springer Netherlands, Dordrecht, 7-24, https://doi.org/10.1007/978-1-4020-9579-5, ISBN 978-1-40209578-8, 2009.

Savelli, E., Rusca, M., Cloke, H., and Di Baldassarre, G.: Don't blame the rain: Social power and the 20152017 drought in Cape Town, J. Hydrol., 594, 125953, https://doi.org/10.1016/j.jhydrol.2020.125953, 2021.

Scopus: Access and use Support Center: https://service.elsevier. com/app/answers/detail/a_id/15100/supporthub/scopus/, last access: 20 April, 2021.

Seneviratne, S. I.: Climate science: Historical drought trends revisited, Nature, 491, 338-339, 2012.

Serdeczny, O., Adams, S., Baarsch, F., Coumou, D., Robinson, A., Hare, W., Schaeffer, M., Perrette, M., and Reinhardt, J.: Climate change impacts in Sub-Saharan Africa: from physical changes to their social repercussions, Reg. Environ. Change, 17, 1585$1600,2017$.

Stahl, K., Kohn, I., Blauhut, V., Urquijo, J., De Stefano, L., Acácio, V., Dias, S., Stagge, J. H., Tallaksen, L. M., Kampragou, E., Van Loon, A. F., Barker, L. J., Melsen, L. A., Bifulco, C., Musolino, D., de Carli, A., Massarutto, A., Assimacopoulos, D., and Van Lanen, H. A. J.: Impacts of European drought events: insights from an international database of text-based reports, Nat. Hazards Earth Syst. Sci., 16, 801-819, https://doi.org/10.5194/nhess16-801-2016, 2016.

Svoboda, M. and Fuchs, B.: Handbook of drought indicators and indices. Integrated drought management programme (IDMP), integrated drought management tools and guidelines series 2, World Meteorological Organization and Global Water Partnership, Geneva, Switzerland, 52, ISBN 978-92-63-11173-9, 2016.

Transparency Int'l: Rotten Deals - How Corruption Spoils Our Food, available at: https://www.transparency.org/en/blog/ rotten-deals-how-corruption-spoils-our-food (last access: 2 February 2022), edited by: Transparency International, 16 October 2019.

Transparency International: Corruption Perceptions Index 2020, available at: https://www.transparency.org/en/cpi/2020 (last access: 2 February 2022), ISBN 978-3-96076-157-0, 2021.

U.S. Drought Monitor: https://droughtmonitor.unl.edu/ (last access: 1 February 2022), 2021.

UN Secretariat General: United Nations Convention to Combat Drought and Desertification in Countries Experiencing Serious Droughts and/or Desertification, Particularly in Africa, Paris, available at: https://treaties.un.org/Pages/ViewDetails.aspx?src= 
IND\&mtdsg_no=XXVII-10\&chapter=27\&clang=_en (last access: 21 May 2021), 1994.

UN Water: What is Water Security? Infographic: available at: https: //www.unwater.org/publications/water-security-infographic/ (last access: 4 March 2021), 2013.

United Nations, Department of Economic and Social Affairs, Population Division: World Population Prospects 2019: Highlights (ST/ESA/SER.A/423), ISBN 978-92-1-148316-1, 2019.

Van Lanen, H., Vogt, J., Andreu, J., Carrão, H., De Stefano, L., Dutra, E., Feyen, L., Forzieri, G., Hayes, M., and Iglesias, A.: Climatological risk: droughts, Science for disaster risk management, Publications Office of the European Union, ISBN 978-9279-606678-6, 271-293, https://doi.org/10.2788/688605, 2017.

Van Loon, A. F., Gleeson, T., Clark, J., Van Dijk, A. I. J. M., Stahl, K., Hannaford, J., Di Baldassarre, G., Teuling, A. J., Tallaksen, L. M., Uijlenhoet, R., Hannah, D. M., Sheffield, J., Svoboda, M., Verbeiren, B., Wagener, T., Rangecroft, S., Wanders, N., and Van Lanen, H. A. J.: Drought in the Anthropocene, Nat. Geosci., 9, 89-91, https://doi.org/10.1038/ngeo2646, 2016a.

Van Loon, A. F., Stahl, K., Di Baldassarre, G., Clark, J., Rangecroft, S., Wanders, N., Gleeson, T., Van Dijk, A. I. J. M., Tallaksen, L. M., Hannaford, J., Uijlenhoet, R., Teuling, A. J., Hannah, D. M., Sheffield, J., Svoboda, M., Verbeiren, B., Wagener, T., and Van Lanen, H. A. J.: Drought in a humanmodified world: reframing drought definitions, understanding, and analysis approaches, Hydrol. Earth Syst. Sci., 20, 36313650, https://doi.org/10.5194/hess-20-3631-2016, 2016 b.

Viglione, A., Borga, M., Balabanis, P., and Blöschl, G.: Barriers to the exchange of hydrometeorological data in Europe: Results from a survey and implications for data policy, J. Hydrol., 394, 63-77, https://doi.org/10.1016/j.jhydrol.2010.03.023, 2010.

Vogt, J. V., Naumann, G., Masante, D., Spinoni, J., Cammalleri, C., Erian, W., Pischke, F., Pulwarty, R., and Barbosa, P.: Drought Risk Assessment and Management, Publications Office of the European Union, ISBN 978-92-79-97469-4, available at: https:// publications.jrc.ec.europa.eu/repository/handle/JRC113937 (last access: 2 February 2022), 2018.

Vollset, S. E., Goren, E., Yuan, C.-W., Cao, J., Smith, A. E., Hsiao, T., Bisignano, C., Azhar, G. S., Castro, E., and Chalek, J.: Fertility, mortality, migration, and population scenarios for 195 countries and territories from 2017 to 2100: a forecasting analysis for the Global Burden of Disease Study, The Lancet, 396, 1285 1306, 2020.

Walker, D., Forsythe, N., Parkin, G., and Gowing, J.: Filling the observational void: Scientific value and quantitative validation of hydrometeorological data from a communitybased monitoring programme, J. Hydrol., 538, 713-725, https://doi.org/10.1016/j.jhydrol.2016.04.062, 2016.

Walker, D. W., Cavalcante, L., Kchouk, S., Neto, G. R., Dewulf, A., Gondim, R. S., Passos Rodrigues Martins, E. S., Melsen, L. A., de Assis de Souza Filho, F., Vergopolan, N., and van Oel, P. R.: Drought diagnosis: what the medical sciences can teach us, Earth's Future, 10, e2021EF002456, https://doi.org/10.1029/2021EF002456, 2022.
Wani, S. P., Rockström, J., and Oweis, T. Y.: Rainfed agriculture: unlocking the potential, CAB International, Wallingford, UK, https://doi.org/10.1017/S0014479709990664, 2009.

Warren, R. F., Wilby, R. L., Brown, K., Watkiss, P., Betts, R. A., Murphy, J. M., and Lowe, J. A.: Advancing national climate change risk assessment to deliver national adaptation plans, Philos. T. Roy. Soc. A, 376, 20170295, https://doi.org/10.1098/rsta.2017.0295, 2018.

Wilhite, D. A. and Glantz, M. H.: Understanding: the drought phenomenon: the role of definitions, Water Int., 10, 111-120, 1985.

Wilhite, D. A.: Drought as a natural hazard: concepts and definitions, in: Drought: A Global Assessment, Vol. I, edited by: Donald, A. W., chap. 1, pp. 3-18, London, Routledge, 2000.

Wilhite, D. A., Svoboda, M. D., and Hayes, M. J.: Understanding the complex impacts of drought: A key to enhancing drought mitigation and preparedness, Water Resour. Manage., 21, 763-774, https://doi.org/10.1007/s11269-006-9076-5, 2007.

Willis, R. M., Stewart, R. A., Panuwatwanich, K., Jones, S., and Kyriakides, A.: Alarming visual display monitors affecting shower end use water and energy conservation in Australian residential households, Resour. Conserv. Recy., 54, 1117-1127, https://doi.org/10.1016/j.resconrec.2010.03.004, 2010.

World Meteorological Organization: Standardized Precipitation Index User Guide (Svoboda, M., Hayes, M., and Wood, D.), WMONo. 1090, Geneva, ISBN 978-92-63-11090-9, 2012.

World Bank: Agriculture, forestry, and fishing, value added (\% of GDP), available at: https://data.worldbank.org/indicator/ NV.AGR.TOTL.ZS? end $=2019 \&$ name_desc $=$ true $\&$ start $=1960 \&$ type $=$ shaded $\&$ view $=$ map $\&$ year $=2016$ (last access: 12 February 2021), 2016.

World Bank: Assessment of the state of hydrological services in developing countries, International Bank for Reconstruction and Development/The World Bank, Washington, DC, available at: https://www.gfdrr.org/sites/default/files/ publication/state-of-hydrological-services_web.pdf (last access: 4 March 2021), 2018.

World Bank: Population growth (annual \%) - World, available at: https://data.worldbank.org/indicator/SP.POP.GROW?locations= 1W\&name_desc $=$ false \&view $=$ map (last access: 4 March 2021), 2019.

Wu, H., Svoboda, M. D., Hayes, M. J., Wilhite, D. A., and Wen, F.: Appropriate application of the standardized precipitation index in arid locations and dry seasons, Int. J. Climatol., 27, 65-79, https://doi.org/10.1002/joc.1371, 2007.

Zargar, A., Sadiq, R., Naser, B., and Khan, F. I.: A review of drought indices, Environ. Rev., 19, 333-349, https://doi.org/10.1139/a11013, 2011. 